Sovereign Risk and Asset and Liability Management_Conceptual Issues

Udaibir S. Das, Yinqiu Lu, Michael G. Papaioannou, and Iva Petrova 
IMF Working Paper

Monetary and Capital Markets Department

\title{
Sovereign Risk and Asset and Liability Management-Conceptual Issues
}

\author{
Prepared by Udaibir S. Das, Yinqiu Lu, Michael G. Papaioannou, and Iva Petrova ${ }^{1}$ \\ Authorized for distribution by Udaibir S. Das
}

October 2012

\section{This Working Paper should not be reported as representing the views of the IMF.}

The views expressed in this Working Paper are those of the author(s) and do not necessarily represent those of the IMF or IMF policy. Working Papers describe research in progress by the author(s) and are published to elicit comments and to further debate.

Abstract

Country practices towards managing financial risks on a sovereign balance sheet continue to evolve. Each crisis period, and its legacy on sovereign balance sheets, reaffirms the need for strengthening financial risk management. This paper discusses some salient features embedded in in the current generation of sovereign asset and liability management (SALM) approaches, including objectives, definitions of relevant assets and liabilities, and methodologies used in obtaining optimal SALM outcomes. These elements are used in developing an analytical SALM framework which could become an operational instrument in formulating asset management and debtor liability management strategies at the sovereign level. From a portfolio perspective, the SALM approach could help detect direct and derived sovereign risk exposures. It allows analyzing the financial characteristics of the balance sheet, identifying sources of costs and risks, and quantifying the correlations among these sources of risk. The paper also outlines institutional requirements in implementing an SALM framework and seeks to lay the ground for further policy and analytical work on this topic.

JEL Classification Numbers: F34, F37, G11, G12, G13, G15, G18

Keywords: Sovereign asset and liability management, sovereign balance sheet, reserve management, debt management

Author’s E-Mail Address: udas@imf.org,ylu@imf.org,mpapaioannou@imf.org, ipetrova@imf.org.

\footnotetext{
${ }^{1}$ We would like to thank Stijn Claessens, Pascal Farahmand, David Grigorian, Allison Holland, Peter Lindner, Elena Loukoianova, Jukka Pihlman, and Han van der Hoorn for helpful comments and suggestions. The work on the paper was undertaken and completed during 2007-10 while Yinqiu Lu and Iva Petrova were with the former Sovereign Asset and Liability Management Division of Monetary and Capital Markets Department. The implications of the current Global Financial Crisis on the SALM framework have not been examined in this paper. The usual disclaimer applies.
} 


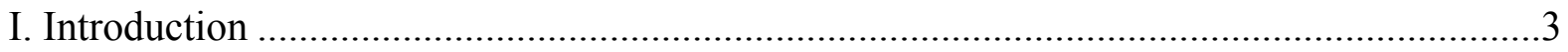

II. Elements of an Sovereign Asset and Liability Management Framework .........................6

A. Defining Sovereign Asset and Liability Management Objectives ..........................

B. Defining Relevant Assets and Liabilities .............................................................. 12

C. Sovereign Asset and Liability Management Methodologies ..................................16

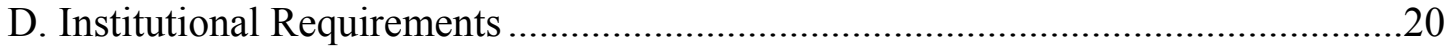

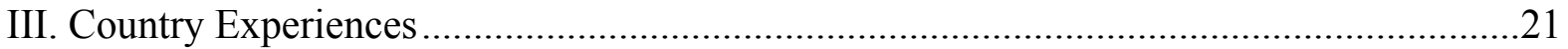

A. Sovereign Balance Sheet and Sovereign Asset and Liability Management

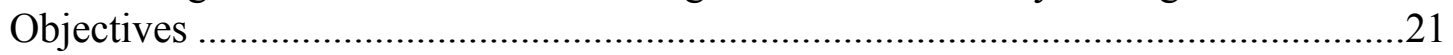

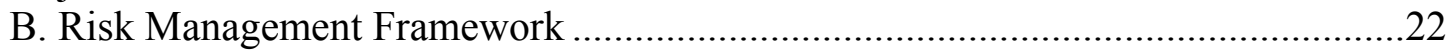

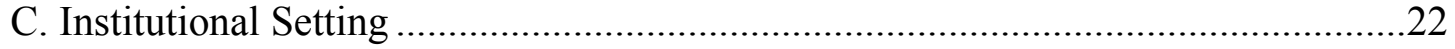

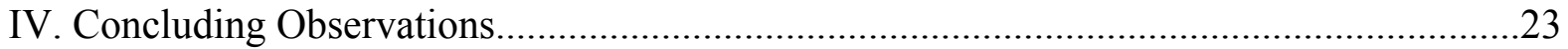

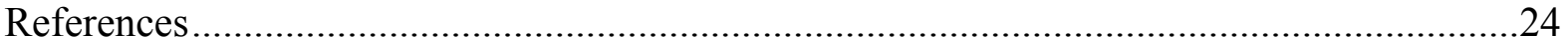

Tables

1. Government Balance Sheet: Government Finance Statistics Manual Definition................13

2. Stylized Economic-Risk Balance Sheet of the Sovereign .............................................15

3. Stylized Sovereign Balance Sheet in the Contingent Claims Analysis .............................16

4. Select Sovereign Asset and Liability Management Methodologies .................................18

Figures

1. Sovereign Asset and Liability Management Framework................................................4

2. Overview of Contingent Claims Analysis for the Sovereign........................................ 36

Boxes

1. Comparison of Risk Management Approaches for Sovereigns and the Private Sector........6

Appendices

I. Select Sovereign Asset and Liability Management

Methodologies.

II. Technical Issues in Sovereign Asset and Liability Management Modeling

and Country Examples 


\section{INTRODUCTION}

The financial crises of the last thirty years have amply demonstrated that unattended public and private sector risks can be at crises' origins. Sovereigns are susceptible to various risks and uncertainties relating to their financial assets and liabilities, depending on the country's level of economic and financial development. Typically, emerging market sovereigns face increased market exposure of their net foreign asset and debt portfolios, especially as they expand access to domestic and international capital markets. Many frontier market sovereigns are exposed to risks arising from terms-of-trade shocks and changes in debt refinancing terms, and tend to be more vulnerable to exogenous shocks than other countries.

Advanced markets face market risk exposure as well, particularly those that rely on capital market access and are systemically important issuers of public debt. In addition, they face other financial risks associated with an aging population, structural issues that need reform ( health and pension), and contingent liabilities arising from systemically important financial or corporate firms, and or potentially weak financial sectors and/or subnational entities. These risks, if realized, could cause a significant fiscal and financial drain and a consequent fall in the country's domestic absorption and potential output.

To help identify and manage effectively the key financial exposures, a sovereign asset and liability management (SALM) framework, based on the balance-sheet approach, can be employed. This framework can also be used to inform the macroeconomic and financial stability policy design. SALM focuses on managing and containing the financial risk exposure of the public sector as a whole, so as to preserve a sound balance sheet needed to support a sustainable policy path and economic growth. The SALM approach entails monitoring and quantifying the impact of movements in exchange rates, interest rates, inflation, and commodity prices on sovereign assets and liabilities and identifying other debt-related vulnerabilities (Rosenberg et al., 2005) in a coordinated if not an integrated way (Figure 1). ${ }^{2}$

The SALM approach can also be utilized to facilitate a country's long-term macroeconomic and developmental objectives such as economic diversification, broadening of the export market, or reducing the dependence on key import products. Further, the SALM approach can help identify long-term fiscal challenges, such as unfunded social security liabilities, implying a future claim on resources (Traa and Carare, 2007). In this context, the SALM framework forms an integral part of an overall macroeconomic management strategy (e.g., Au-Yeung et al., 2006, Bolder, 2002, CREF South Africa, 1995, Danmarks Nationalbank, 2000, Grimes, 2001, Horman, 2002).

For commodity-exporting countries, the SALM approach can highlight the potential asset management challenges that stem from a medium-term fiscal strategy (Leigh and Olters, 2006). For example, high commodity prices lead to higher revenues, concurrently strengthening their (unadjusted) fiscal positions. However, commodity depletion leads to

\footnotetext{
${ }^{2}$ The European exchange rate crisis in 1992 and the Mexican crisis in 1994-95 are examples of how possible maturity and currency mismatches in sovereign balance sheets expose countries to market volatility and make them vulnerable to external shocks.
} 
lower future revenues, which could be mitigated with appropriate asset management to ensure that future fiscal expenditures are sustainable.

\section{Figure 1. SALM Components}

\begin{tabular}{|c|c|c|}
\hline \multicolumn{3}{|c|}{$\begin{array}{l}\text { SALM Goals } \\
\text { - Preserve positive sovereign financial n } \\
\text { - Support sustainable macroeconomic }\end{array}$} \\
\hline \multicolumn{3}{|c|}{ SALM Constraints } \\
\hline Sovereign Balance Sheet Constraints & Domestic Constraints & External Constraints \\
\hline $\begin{array}{l}\text { - Initial sovereign debt level and } \\
\text { composition } \\
\text { - Initial sovereign asset level and } \\
\text { composition }\end{array}$ & $\begin{array}{l}\text { - Policy interest rates and inflation } \\
\text { - Contingent liabilities } \\
\text { - Institutional organization } \\
\text { - Market development }\end{array}$ & $\begin{array}{l}\text { - Exchange rates } \\
\text { - External interest rates } \\
\text { - Commodity prices } \\
\text { - Asset prices } \\
\text { - Market risk appetite }\end{array}$ \\
\hline • & $\begin{array}{c}\text { SALM Tools } \\
\text { - Financial risk models } \\
\text { - Contingent claims approach } \\
\text { tuitive risk management approa }\end{array}$ & \\
\hline
\end{tabular}

From a portfolio perspective, the SALM approach could help detect sovereign risk exposures. It allows analyzing the financial characteristics of the balance sheet, identifying sources of costs and risks, and quantifying the correlations among these sources ((Claessens, 2005; Lu, Papaioannou, and Petrova, 2007; Zacho, 2006). If the match of financial characteristics of the assets and liabilities is only partial, risk management could focus on the unmatched portions, i.e., net financial positions. In a short- to medium-term perspective, a financial risk management strategy could then be developed to reduce exposures. For example, if the net position results in a liability exposure, appropriate strategies should be developed to manage the risks associated with such exposure. ${ }^{3}$

The application of the SALM framework could be constrained by a number of policy and institutional factors. Monetary policy objectives have an impact on SALM strategies, by affecting either market - interest rate and exchange rate-risk management or directly the size

\footnotetext{
${ }^{3}$ On the liability side, debt management strategy aims at minimizing debt service cost subject to a prudent level of risk. On the asset side, strategic asset management aims primarily at accumulating an adequate level of net foreign assets, including foreign exchange reserves, to be used for conducting effective monetary and foreign exchange policies, and as a buffer against external shocks. Also, it may involve the management of "excess" foreign currency assets (e.g., reserves above an adequate level), including through the design and management of investment portfolios through sovereign wealth funds (SWFs) so that returns on international assets can be enhanced and passed on to future generations, or help offset the impact of domestic and external shocks on the fiscal position.
} 
of the balance sheet. ${ }^{4}$ Fiscal policy objectives that aim at limiting annual debt service costs may put constraints on the duration and currency composition of public debt, since high shares of short-term debt are perceived to lead to greater volatility of service costs.

The structure of international and domestic capital markets also shapes the SALM implementation. Some developing countries cannot issue domestic debt because of illiquid and/or shallow domestic debt capital markets and a lack of a reliable local investor base. Their attempts to issue domestic-currency external debt have also not been well-received in international markets owing, in part, to their vulnerability to shocks, restrictions on foreign investors to buy local-currency debt (e.g., on type of instruments, minimum holding period), poor transparency, and/or a lack of interest rate and exchange rate hedging instruments.

In addition, some have argued that combining the management of sovereign assets and liabilities under one framework may not be optimal. ${ }^{5}$ Cassard and Folkerts-Landau (2000) points out a potential conflict of interest between monetary policy and debt management if a central bank assumes an operational role or actively participates in debt markets. For example, the central bank may be reluctant to increase the interest rates in the face of growing inflation concerns for fear of raising debt rollover costs. Also, the central bank's intervention policy may be in conflict with its daily task of managing the liquidity of the foreign currency debt.

While risk management approaches for sovereigns may differ from those for the private sector (Box 1), this paper discusses the salient features embedded in countries' approaches to SALM, including main objectives, definitions of relevant assets and liabilities, and methodologies used in obtaining optimal debt and asset outcomes. These considerations are typically taken into account when developing an analytical SALM framework, which may evolve into an operational instrument for formulating asset and debt/liability management strategies. Also, the paper outlines common institutional requirements and constraints in implementing an SALM framework, and, based on select country experiences with the SALM approach, draws some stylized lessons and general policy guidelines on adopting an SALM approach.

The rest of the paper is organized as follows: Section II defines the SALM approach, and describes the main elements of the SALM framework. Section III takes a look at select country experiences to point out how the SALM framework has been applied. Section IV provides some concluding remarks.

\footnotetext{
${ }^{4}$ A policy of stable exchange rates will keep the size of the international reserves, part of a sovereign's assets, out of the control of sovereign asset and liability managers. It may also limit the proportion of domestic floating rate debt if the central bank increases interest rates to defend the currency (de Montpellier, 2000).

${ }^{5}$ Admittedly, the more conventional set-up with the central bank managing some of the sovereign's financial assets could often be prone to conflicts of interest. The way an exchange rate regime is managed or interest rate policy measures are taken could have adverse portfolio effects for the central bank.
} 


\section{Box 1. Comparison of Risk Management Approaches: Sovereigns and the Private Sector}

Similar to the private sector, sovereigns also face financial risks from various channels. At the macro level, both sovereigns and the private sector face business cycle risk often linked to changing global or domestic economic climate, demographic risk, and risks brought by natural disasters. At the micro level, balance sheets of both could be affected by adverse movements in interest rates, exchange rates, credit risk, inflation rates, systemic risk factors, and commodity prices.

These risks, if not managed properly, will affect the smooth operations for both sovereigns and the private sector. In the case of sovereigns, the risks could expose them to external vulnerability and/or put them under debt stress. For the private sector, companies may not have an adequate cash flow to meet either their operating expenses or debt obligations, or could become undercapitalized or insolvent.

Nevertheless, the risk management practices of the sovereigns and the private sector differ in complexity and scope, available tools, and systemic importance. First, balance sheet reporting used by the private sector clearly specifies assets, liabilities, and equity, while the existence of international accounting standards simplifies the comparison between companies. In the case of sovereigns, lack of a clear definition of a sovereign balance sheet, incomplete reporting of public sector balance sheets - often containing assets and liabilities that are difficult to quantify with precision — and hurdles to consolidate all public sector balance sheets, make risk management difficult to implement.

Second, traditional risk management tools available to private companies may not be available to sovereigns, or the markets cannot absorb the required transaction amount by sovereigns. For example, some sovereigns may not be well-equipped to use financial derivatives to manage their risks. Since domestic interest rates, exchange rates, and inflation rates are linked to macroeconomic policy objectives, sovereigns may not be in a position to actively use derivatives to hedge or manage risk as their use could get mis-read by the $b$ the markets. Further, the purchase of credit derivatives to cover other sovereign credit exposures could become politically controversial.

Third, sovereigns face reputational risks and therefore public scrutiny if large losses incur from using derivatives. Daniel (2001) elaborates on the political pressure faced by the Ecuadorian authorities in early 1993 stemming from losses connected to the option and swap deals conducted by the central bank and the monetary board.

Finally, the risk management practices of a sovereign could have systemic implications. Thus, in a worst-case scenario, a sovereign under debt distress could trigger a financial and economic crisis. In contrast, a wellmanaged sovereign with sound macroeconomic policies, investor-friendly environment, and high credit ratings could mitigate the risk management burden of its private sector, e.g., by reducing the risk premium for international market access. Also, some sovereigns, especially where the private sector is not sophisticated enough, may become risk managers of last resort by providing implicit guarantees on private sectorespecially, foreign exchange- exposures.

\section{ELEMENTS OF AN SALM FRAMEWORK}

Based on existing literature, this section focuses on the theoretical underpinnings of the SALM approach. In particular, it describes the relevant assets and liabilities to be included in the analysis (Das, 2011), and presents the main methodologies used within an SALM framework. These conceptual and methodological issues are used to compare and assess country experiences with SALM. 


\section{A. Defining SALM Objectives}

The elements of an SALM framework depend upon the stated economic policy objectives. In particular, elements such as the balance sheet definition, analytical framework, targets, and instruments are usually chosen keeping in view the authorities' economic policy objectives to be achieved through an SALM. Hansen (2003) presents a useful overview in the case for New Zealand, though it is applicable across other countries. It categorizes the objectives in 7 groups: (i) to neutralize the impact of the size and composition of the government balance sheet on economic welfare; (ii) to minimize the expected deadweight losses of taxation; (iii) to minimize the risk of unstable fiscal and monetary policies; (iv) to minimize the agency cost of government; (v) to maximize opportunities for efficient risk sharing in a setting with incomplete capital markets; (vi) to provide optimal risk management in the presence of asymmetric information; and (vii) to minimize efficiency risks. We focus below on the elements of SALM as they pertain to countries' policy objectives and constraints.

\section{Case 1: Maximizing long-term social welfare when foreign currency assets are considered}

As the composition of government debt and other financial liabilities is being determined, other components of the sovereign balance sheet-such as domestic currency financial assets and foreign-currency denominated financial assets, including international reserves - come into play. A number of emerging market and developing countries still suffer from the "original sin," which allows them to issue only short-term local currency debt. ${ }^{6}$ They may also suffer from other institutional constraints - a very narrow investor base or undeveloped government securities markets-which limit the government's ability to select the optimal government debt structure. In such cases, the composition of government debt may be driven by demand considerations, which may amplify the sovereign balance sheet risks. Asset components of the sovereign balance sheet - most commonly the international reservescould be used to offset such balance sheet risks (Bohn, 2002).

A main objective for the sovereign to hold financial assets in foreign currency is to help meet balance of payments and intervention needs so that intertemporal consumption can be smoothened. In this role, such types of sovereign financial assets need to be sufficiently liquid in order to redistribute the burden of random shocks throughout time. ${ }^{7}$ Mundell (1973) devises a liquidity index, which determines the optimal level of reserves in months of imports as an inverse ratio of the velocity of money. For example, for a country with income velocity of money equal to four, this rule would imply an optimal level of reserves equal to three months of imports. The three-month rule has since been accepted as a benchmark in assessing how

\footnotetext{
${ }^{6}$ Eichengreen and Hausmann (1999) call "original sin" a "situation in which the domestic currency cannot be used to borrow abroad or to borrow long term, even domestically."

${ }^{7}$ According to the $6^{\text {th }}$ edition of the Balance of Payments Manual, "Reserve assets are those external assets that are readily available to and controlled by monetary authorities for meeting balance of payments financing needs, for intervention in exchange markets to affect the currency exchange rate, and for other related purposes (such as maintaining confidence in the currency and the economy, and serving as a basis for foreign borrowing)".
} 
well countries are insured against shocks, particularly in the case of economies with relatively closed capital accounts and no or limited market exposure (IMF, 2004).

To appreciate fully the role of international reserves in smoothing intertemporal consumption, one would need to focus on the consolidated balance sheet of the government and the central bank. This would require accounting for all existing and contingent liabilities of the sovereign and balance sheet risks stemming from the exchange rate regime. In emerging market countries with relatively open capital accounts and integrated financial systems, reserves are more appropriately measured in terms of short-term public and private debt by residual maturity. Bussière and Mulder (1999) shows that an adequate level of reserves should cover one year's worth of debt obligations. Additional considerations in determining reserve adequacy are the strength of a country's economic fundamentals (possible exchange rate overvaluation, current account balance), the notional value of short-term public sector net derivatives positions, and possible weaknesses in the banking system that could lead to passing foreign currency liabilities to the government. IMF (2011) proposes a new framework to assess reserve adequacy which takes into account the external debt level, exports, and broad money.

The composition of international reserves, from an SALM perspective, should derive from the type of shocks that they are meant to offset. Typically, a portion of highly liquid reserves is determined through an assessment of the potential liquidity needs based on balance of payments stress tests and past interventions. Also, countries that have limited international market access may structure their reserves so that they match the currency composition of their future imports. In countries where reserves provide coverage for short-term debt, their currency composition should match the currency composition of their short-term debt.

\section{Case 2: Maximizing long-term social welfare in the case of an ample amount of foreign currency assets}

Risk-return considerations are gaining increasing importance in managing a sovereign's foreign-currency denominated financial assets. The significant growth in official foreign exchange reserves, for instance, has highlighted the need to curtail opportunity costs, especially for the portion of such assets having a low probability of being used for balance of payments or intervention purposes. The challenge then becomes how to manage a growing part as an investment portfolio while mitigating currency, interest rate, credit and operations risks (Kreuser, 2002, and International Monetary Fund, 2001).

In principle, this class of sovereign assets could be used to buy back external debt and reduce the size of the government balance sheet. This lowers the risk of currency and maturity mismatches and the carry cost. If these assets are in excess even after debt redemptions and buy-backs, they could be allocated in Sovereign Wealth Fund-type arrangements with clear rules for funding and withdrawals for macro-fiscal considerations. Cases that an investment fund appears to be a sensible solution include: (i) a local economy that cannot absorb additional spending without overheating; (ii) windfall profits are likely to disrupt the domestic economy ("Dutch disease" effects); (iii) an uncertain future, especially in countries that are rich in natural resources that are non-renewable; (iv) a country that may need to diversify its asset base (Nugée, 2000). 
There are mainly five types of SWFs based on their stated policy objectives: (i) stabilization funds, which are set up by natural-resource rich countries to insulate the budget and economy from volatile commodity prices (usually oil); (ii) savings funds, which are intended to transfer wealth (e.g., nonrenewable assets transformed into diversified financial assets) across generations; (iii) development funds, which allocate resources to priority socio-economic projects, such as infrastructure; (iv) pension reserve funds, which target pension and/or contingent-type liabilities on the government's balance sheet; (v) reserve investment corporations, which are intended to reduce the negative carry costs of holding reserves or to earn higher return on ample reserves while the assets in the funds are still counted as reserves.

Countries could establish more than one type of SWFs, at the same time, depending on stated objectives. Also, as SWF assets grow, their objectives may change to hedge risks originating in different components of the sovereign balance sheet. ${ }^{8}$ For example, an SWF may originally be set up as a stabilization fund to smooth fiscal revenue or sterilize foreign currency inflows in a natural resource exporting country. As the assets in the SWF continue to grow beyond the level needed for the purpose of stabilization, the government may carve a portion of the assets, revisit the objectives and redesign the structure of the SWF to broaden its objective (e.g., Norway). This may lead to assets being split into several tranches for different objectives, or the creation of separate funds with different objectives (IMF, 2007). ${ }^{9}$ Often, such separation focuses on stabilization relating to idiosyncratic fiscal/macro shocks that may occur in the longer term rather than just a single business cycle, e.g., the ageing of the population or the exhaustion of the natural resources that provide for the SWF accumulation (e.g., Russia, Chile).

\section{Case 3: Maximizing long-term social welfare in the case of a net-debt position}

\section{Tax smoothing objective}

The most common theoretical approach for an SALM framework is based on the idea that taxes create economic distortions that could be mitigated through an SALM setup. Lump-sum taxes, in combination with other Ricardian equivalence conditions, render debt and taxes perfect substitutes in government financing. If taxes are distortionary, tax smoothing over time becomes an important determinant of the debt level (Bohn, 1990). In addition, if there is uncertainty about real interest rates, levels of public outlays, and the tax base (aggregate consumption or GDP), the structure of debt matters for tax smoothing (Barro, 1995). ${ }^{10}$

\footnotetext{
${ }^{8}$ In the context of developing countries, see IMF, 2012.

${ }^{9}$ The institutional arrangements for managing the different types of SWF arrangements can be classified broadly in three categories. The first two pertain to those managed by (a) the central bank, and/or (b) an independent agency. A third category of SWFs consist of those funds already established that acquire the modality of "tiers of accounts", that is, separate funds for different purposes. In some instances, the central bank transfers funds to the SWF, while in other cases funds are transferred to the central bank for management purposes.

${ }^{10}$ Barro (1995) considers a case where the government has a choice over the structure of the debt portfolio, including maturity, nominal or indexed bond, and contingency on other variables.
} 
The government would try to structure its portfolio so that non-diversifiable risks are hedged in order to reduce taxation costs. In cases where a rise in taxes yields proportional welfare losses, the optimal strategy for the government would be to minimize the average long-term tax and choose a portfolio with the highest return, even if this implies exceptionally high leverage. When the cost of taxation increases more than proportionally, the optimal government strategy is to minimize the variance of the taxation path ${ }^{11}$ by issuing debt that is negatively correlated with public spending and positively correlated with tax returns (e.g., productivity shocks) (Barro, 1995).

In this context, social welfare risk could loosely be defined as the possibility that services delivered have to be severely curtailed for a given level of taxes, or that taxes will have to be increased to maintain a given level of government services, both of which could result from different situations, including sovereign illiquidity and insolvency. Thus, the tax-smoothing literature provides a well-defined objective for SALM: to minimize the need to raise taxes or the need to curtail services when faced with unexpected shocks causing a permanent fall in fiscal revenues or a rise in the value of liabilities (Currie and Velandia, 2002).

Proper debt instruments should therefore be used to insure against shocks to the government revenues, public spending, and interest rates. In particular, when encompassing both interest rate risk and risk of a liquidity crisis, the rationale is to avoid exposure to exchange rate variations and refinancing risk. While concerns over exchange rate variations suggests that a domestic-currency denomination of public debt is more appropriate, refinancing concerns suggest that a debt manager should prefer long-term debt and a balanced maturity structure (Missale, 1997).

\section{Smoothing of fiscal balances objective}

An alternative analytical framework of the sovereign's objectives applies to the case when the government faces a constraint on its budget deficit. The framework assumes that output and inflation affect revenues and the fiscal position positively, and that the fiscal policy does not impact interest rates.

The optimal government debt structure depends on the correlations between output, inflation, and interest rates. With a normal upward sloping yield curve the government will achieve a stable fiscal position if it issues short-term debt when output and inflation are low, because the fiscal revenues are likely to be sufficient to cover only low interest payments given the fiscal constraint. If output and inflation are positively correlated, the government's optimal debt strategy would include the issuance of inflation-indexed bonds or variable-rate bonds, which will offset cyclical deficits. In an inflation targeting environment, the optimal debt structure also suggests that the government should issue only long-term and inflation-indexed debt. On the other hand, if the monetary authorities are more concerned about output stabilization, the optimal debt composition should contain short-term bonds. In this case, inflation-indexed bonds are not an appropriate choice, as the inflation rate may be very volatile and generally uncorrelated with output.

\footnotetext{
${ }^{11}$ Tax increases cost more than could be saved with an equal size in tax reductions.
} 
In countries employing appropriate debt/liability management practices, the main objective is to minimize the cost of government financing and debt service while incurring a prudent degree of risk (IMF and the World Bank, 2001). ${ }^{12}$ To the extent that the variability of the debt servicing costs is reduced in this process, such an objective also minimizes the variability of the budget deficit. For example, a macroeconomic model relating debt-servicing costs to the government budget deficit allows assessing the smoothing properties of the debt management strategy. In practice, this has been achieved through simulations of the ratio of the debt servicing costs to GDP, as GDP often co-varies with the government's primary fiscal position. In this case, a smooth ratio of debt servicing costs to GDP ensures low variability of the overall fiscal balance.

\section{Case 4: Reducing balance sheet risks—reduce/eliminate foreign currency and maturity mismatches}

\section{Foreign currency mismatches}

Foreign currency exposure often has two dimensions: (i) liquidity risk - the ease or difficulty of obtaining foreign exchange; and (ii) balance sheet risk - the sensitivity of the borrower or investor's net wealth or net income to changes in the exchange rate.

In a well-defined debt management framework, the desired output is a strategic benchmark that defines the optimum debt structure, including the optimum share of foreign-currency debt in total debt. The optimum currency composition of debt is usually determined by the minimization of projected debt servicing costs (assumed as the overarching primary objective of debt management in most countries) subject to constraints regarding (i.e., not exceeding) certain foreign exchange-, interest rate-, credit- and liquidity-risk levels (which can be considered as additional primary objectives of debt management).

If an SALM framework is employed, the optimum currency composition of debt is often determined by an optimization that takes into account both the minimization of projected debt servicing costs and maximization of the risk-adjusted return of the country's assets (in particular, international reserves and projected primary balances) subject to constraints regarding specified risks and the country's asset-liability structures. This approach, in essence, espouses the view that the currency composition of the debt (liabilities) should closely match that of the assets in a sovereign's balance sheet (Papaioannou, 2009).

\section{Maturity mismatches}

Most measures of interest rate exposure focus on balance sheet risk. The sensitivity of a borrower's net worth (or net income) to changes in short-term interest rates depends on the

\footnotetext{
${ }^{12}$ It has been argued that in managing debt, sovereign's do not attempt to smooth taxes, as suggested by theoretical economists, but are mostly concerned with the variability of interest expenditures. The reason for this divergence between theory and practice is that debt managers are responsible only for achieving the debt management objectives, are not responsible for the implementation of tax plans, and view interest rate expenditures as the only relevant variable. Piga (2001) claims that deficit smoothing is a more plausible debt management objective based on countries' recent experiences.
} 
average maturity of the debt, the extent to which the coupon on long-dated debt is linked to short-term interest rates, and the structure of assets on the balance sheet of the borrower.

Also, when gauging risk exposures based on assessments of interest rate and currency mismatches, it is important to take into account the impact of derivative transactions on the transfer of economic risk and, hence, there is a need to account for off-balance sheet exposures.

\section{Case 5: Achieving other objectives}

It is understood that SALM objectives should always be consistent with the overall macroeconomic policy framework. However, in addition to the SALM objectives outlined above, other objectives may explicitly or implicitly be included in an SALM framework. Usually, these SALM objectives include the achievement of various public policy goals (attainment of a better credit rating, correction of externalities, provision of certain public services, and income redistribution and poverty reduction).

\section{B. Defining Relevant Assets and Liabilities}

There are two main challenges in defining relevant assets and liabilities in an SALM framework. The first challenge is to determine the items of assets and liabilities that should be included in an SALM framework and, therefore, in a sovereign balance sheet. A narrow definition of SALM includes international reserves and foreign currency debt. Broader definitions include all sovereign financial assets and liabilities, except nonfinancial ones. ${ }^{13}$

The second relates to the choice of the relevant accounting practices. The value of assets and liabilities depends much on which accounting measure is used: mark-to-market valuation or historical price. As bond prices move inversely with interest rates and changes in exchange rates affect the market value of external debt, mark-to-market valuation leads to larger fluctuations in the value of debt compared to the use of historical prices. For contingent liabilities, such as unfunded pension rights, the value depends on assumptions regarding the discount rate, life expectancy, and inflation rate. At least for some assets, the market value and historical value will yield a significant gap. For example, the equity in loss-making stateowned companies, if evaluated using market values, may be much lower than if evaluated using historical values. Also, it is difficult to evaluate the value of assets that do not generate profits (e.g., national parks) or that have yet to generate profits (e.g., underground assets).

\section{Government finance statistics}

The IMF's Government Finance Statistics Manual, 2001 (GFSM) provides a definition and classification of the general government sector's balance sheet at the end of the accounting

\footnotetext{
${ }^{13}$ There are two reasons that nonfinancial assets and liabilities are excluded in SALM. The first one is that nonfinancial assets and liabilities often do not generate cash flows, and thus it is difficult to measure their price sensitivities to changes in economic variables such as interest rates and exchange rates. The second one is that in order to use market valuation, assets and liabilities should be able to be approximately measured using market variables, which may not be available for nonfinancial ones.
} 
period. Assets are those over which the general government has ownership rights, and from which it may derive economic benefits by holding or using them over a period of time. Thus, assets are classified as either financial or nonfinancial. Liabilities are obligations to other institutional units. Liabilities and financial assets are classified first by the residency and then by type of instruments (Table 1). Net worth, which is the difference between assets and liabilities, is a measure for assessing the sovereign's (fiscal) sustainability. If the market value of nonfinancial assets is difficult to assess or the analysis requires only focusing on the financial assets, the relevant sustainability measure is net financial worth.

Table 1. Government Balance Sheet: GFS Definition

\title{
Assets Liabilities
}

\section{Financial Assets (domestic and foreign) Currency and deposits Securities other than shares Loans \\ Shares and other equity}

Insurance technical reserves

Financial derivatives

Other accounts receivable

Monetary gold and SDR

\author{
Liabilities (domestic and foreign) \\ Currency and deposits \\ Securities other than shares \\ Loans \\ Shares and other equity (public corporations \\ only) \\ Insurance technical reserves \\ Financial derivatives \\ Other accounts payable
}

\section{Net Financial Worth}

\author{
Nonfinancial Assets \\ Fixed assets \\ Inventories \\ Valuables \\ Nonproduced assets
}

Net Worth

Source: IMF, Government Finance Statistics Manual, 2001.

It should be noted that the GFSM covers all entities that affect fiscal policies, i.e., entities that are wholly devoted to the economic functions of the government. However, if these entities carry out their functions in a commercial manner, they are part of the public sector but not part of the general government. The central bank's balance sheet is not part of the general government balance sheet according to the GFSM. Nevertheless, there are some exceptions, especially when some of the functions of a monetary authority are carried out by units of the general government, rather than the central bank. For example, government units - which are not part of the central bank and are financially integrated with the government-issuing currencies, maintaining international reserves, managing government (foreign exchange) funds, or conducting transactions with the IMF, are recorded in the balance sheet of the general government.

Even when all monetary functions are conducted by the central bank, the GFSM encourages compiling statistics on the central bank and other public entities conducting central bank activities. The activities of the central bank and changes in its net worth may affect the sustainability analysis of the government, especially if the government assumes debt incurred 
by the central bank or the central bank is involved in debt rescheduling or restructuring operations with the government (regardless of whose debt is being rescheduled or restructured). Therefore, for the purposes of risk analysis, the GFSM balance sheet definition does not prohibit an integrated treatment of the general government and the central bank (or any other separate public sector entity).

\section{Broader sovereign balance sheet definitions}

In general, there are several unambiguous items of financial assets and liabilities to be included in a broader definition of a sovereign balance sheet. A comprehensive sovereign balance sheet incorporating all of these elements is provided by Merton (2007) (Table 2). It is based on economic rather than accounting principles, accounting for underlying intertemporal objectives of the sovereign and including future incomes and expenditures.

On the asset side, a country's foreign reserves and long-term funds, such as a sovereign wealth fund, are part of sovereign assets. Cash, securities, loans, and receivables owned by the government are also sovereign assets. Equity in state-owned-companies with profits is also counted as sovereign assets. On the liability side, public debt is included irrespective of whether it is issued by the central bank or the government. Also, the value of debt reflects changes in interest rates, exchange rates, or the inflation rate. ${ }^{14}$

Other items such as contingent liabilities may also be included, although they are more difficult to quantify. Contingent liabilities are a potential source of government cash outflow, which has to be met through either increasing borrowing or selling assets (Currie and Velandia, 2002). Contingent liabilities are divided into explicit and implicit ones. Credit guarantees and state insurance schemes are explicit contingent liabilities, while implicit contingent liabilities include potential financial system bail-outs, corporate sector bail-outs, natural disasters, etc. Contingent liabilities are more likely to be realized during economic recessions, when government borrowing requirements tend to be high. Valuations of contingent liabilities depend on many assumptions, including probability of defaults and recovery rates, which are difficult to estimate.

\footnotetext{
${ }^{14}$ Inflation will reduce the real value of non-indexed domestic debt, while the depreciation of local currency will inflate the value of external debt measured in local currency.
} 
Table 2. Stylized Economic-Risk Balance Sheet of the Sovereign

Assets

Liabilities

Present Value of Incomes from:

Taxes

Fees

Seigniorage

Balances of:

Cash

Currency Reserves

Investments (pension and wealth funds)

Government-owned enterprises

Infrastructure

Real Estate

Other assets

\section{Present Value of Nondiscretionary \\ Expenses on:}

Social and economic development

Economic development

Government administration

\author{
Balances of: \\ Monetary base \\ Government debt \\ In domestic currency \\ In foreign currency \\ Pension Liabilities
}

\section{Contingent claims (explicit and implicit) \\ Guarantees to banks and nonbanks \\ Guarantees on retirement income \\ Guarantees on social welfare}

Net worth

Net financial worth

Source: Merton (2007).

As one of a sovereign's largest assets is the ability to collect taxes, the sovereign balance sheet definition includes the present value of government revenues on the asset side and the present value of government expenditures on the liability side. The inclusion of the present value of government budget entails an asset-driven borrowing - linking the future debt-service costs to the government's ability to serve the debt-and liability-driven investment strategy (Risbjerg and Holmlund, 2005). In essence, the government has to assess whether the debt-service costs from new debt can be met by the returns of current assets and future cash flows from revenue. The investment decision will be examined against the need to service debt. If the balance sheet consists of a large share of floating-rate debt, it is advisable to have an asset portfolio with similar interest rate characteristics. ${ }^{15}$

Another definition of the sovereign balance sheet is presented in the framework of the contingent claims analysis (CCA). The CCA approach (Gapen et al., 2004 and 2005) includes foreign currency debt, domestic currency debt, and base money - where prices can be observed in the markets - as sovereign liabilities (Table 3). The market value and volatility of sovereign assets are derived from option pricing formulas that take the market price of domestic currency liabilities, volatility of domestic currency liabilities, foreign currency liabilities, risk-free interest rate, and time as inputs.

\footnotetext{
${ }^{15}$ This analysis is effective only if a medium-term budget framework is in place, and accrual-based fiscal accounting is used to obtain an accurate picture of the fiscal performance.
} 
Table 3. Stylized Sovereign Balance Sheet in the CCA

Assets

Liabilities

International reserves

Net fiscal assets (discounted value of primary

fiscal surpluses)

Value of money issuance (seigniorage, or

zero for countries using another country's

currency as a legal tender)

Other assets less guarantees

Source: Papaioannou and Souto (2007).
External debt

Equity

Domestic debt

Base money

\section{SALM Methodologies}

\section{Intuitive frameworks}

Many governments use some form of SALM in which they try to identify risks and vulnerabilities of the sovereign assets and liabilities, without necessarily identifying an economic form of the sovereign balance sheet or establishing SALM objectives. In these cases, governments often determine specific debt management or reserve management strategies that reduce certain exposures and reduce balance sheet vulnerabilities, without always quantifying the risks. Further, they may use a balance sheet in conceptual terms to visualize the interrelationships between different assets and liabilities to determine the direction in which these assets and liabilities need to be changed.

One issue that most may readily recognize is the need to maintain a low level of foreign currency and short-term debt. As government revenues are typically denominated in domestic currency, foreign currency debt would expose them to a consequent currency risk. Short-term debt is to be avoided in order to reduce the rollover and refixing risks that government funding could face.

In developing countries, international reserves could be directly linked to external debt service. To the extent that domestic companies have limited access to financing in international markets, public and total external short-term debt by residual maturity may coincide. In this case, it may be reasonable to match the currency and maturity structure of reserves with that of the public debt, as a simple natural hedging strategy. However, as local currency government debt markets develop and financial integration deepens, public debt takes a decreasing share in external debt. In this process the objectives of reserve and debt management become increasingly more complicated and difficult to coordinate.

\section{Select SALM methodologies}

Several methodologies could be used to obtain an optimal allocation of reserves and/or an optimal debt structure (Table 4, and Appendix I). For example, the mean-variance approach is primarily used to determine an optimal allocation of assets, based on a prespecified upper limit on portfolio volatility. Also, two variants of the mean-variance approach, the Value-at-Risk $(\mathrm{VaR})$ and Cost-at-Risk (CaR) approaches are commonly used to determine an optimal reserve portfolio $(\mathrm{VaR})$ or an optimal debt structure $(\mathrm{CaR})$ with a certain probability. Note that all optimal solutions from mean-variance type approaches depend on exogenously determined 
(ad hoc) levels of risk to be assumed by the government. In essence, the mean-variance framework assumes that there are preconceived (e.g., by the government - the Minister of Finance, or the Governor of the central bank) value amounts for the various types of risk that are imposed on the selection process for the optimal allocations. When a government's objective function regarding risk and return (for the various asset strategies) and risk and cost (for the various debt strategies) is to be taken into consideration in determining optimal allocations, instead of a prespecified level of risk, the Multivariate Adaptive Regression Splines (MARS) method could be an appropriate one. Finally, when the criterion for deciding on optimal allocations is minimization of credit risk for the government, i.e., default probability, then the Contingent Claims Analysis (CCA) approach may be suitable. 
Table 4. Select SALM Methodologies

\begin{tabular}{|c|c|c|c|c|}
\hline Approach & SALM Objective & Use of the approach & Assumptions & $\begin{array}{c}\text { Data } \\
\text { Requirements }\end{array}$ \\
\hline $\begin{array}{l}\text { Mean-variance } \\
\text { approach } \\
\text { (Markowitz, 1952, } \\
\text { and extensions) }\end{array}$ & $\begin{array}{l}\text { To maximize (net) } \\
\text { asset returns, given a } \\
\text { set of restrictions on } \\
\text { risk, liquidity, etc. }\end{array}$ & $\begin{array}{l}\text { To find the optimal portfolio (strategic asset, } \\
\text { debt) allocation, given a certain degree of } \\
\text { risk tolerance. }\end{array}$ & $\begin{array}{l}\text { Path of the instruments' rate of return } \\
\text { and covariance matrix of the returns, } \\
\text { level of (social) risk aversion (volatility } \\
\text { of the portfolio returns) or a specific } \\
\text { utility function. }\end{array}$ & $\begin{array}{l}\text { Sovereign balance } \\
\text { sheet data. }\end{array}$ \\
\hline Value-at-risk & $\begin{array}{l}\text { To maximize (net) } \\
\text { asset returns, given a } \\
\text { certain set of } \\
\text { restrictions on risk, } \\
\text { liquidity, etc. }\end{array}$ & $\begin{array}{l}\text { To determine the maximum volatility of the } \\
\text { (net) asset portfolio returns used in a mean- } \\
\text { variance approach based on the size of } \\
\text { tolerable loss of (net) asset returns } \\
\text { (government net worth/capital preservation } \\
\text { requirement), given that no specific utility } \\
\text { function is used. }\end{array}$ & $\begin{array}{l}\text { A well-defined distribution function of } \\
\text { net (asset) returns (no "fat tails"); and } \\
\text { size of tolerable loss (net worth/capital } \\
\text { preservation requirement). }\end{array}$ & $\begin{array}{l}\text { Historical time- } \\
\text { series of the (net) } \\
\text { asset returns to } \\
\text { estimate their } \\
\text { distribution } \\
\text { properties (mean } \\
\text { and variance). }\end{array}$ \\
\hline Cost-at-risk & $\begin{array}{l}\text { To minimize borrowing } \\
\text { costs, given a certain } \\
\text { set of restrictions on } \\
\text { risk, liquidity, etc. }\end{array}$ & $\begin{array}{l}\text { To determine the maximum volatility of the } \\
\text { debt portfolio costs used in a mean-variance } \\
\text { approach based on the size of tolerable debt } \\
\text { costs (government net worth preservation } \\
\text { requirement), given that no specific utility } \\
\text { function is used. }\end{array}$ & $\begin{array}{l}\text { A well-defined distribution function of } \\
\text { bond yields (no "fat tails"); and size of } \\
\text { tolerable debt cost (net worth } \\
\text { preservation requirement). }\end{array}$ & $\begin{array}{l}\text { Historical time- } \\
\text { series of bond } \\
\text { yields to estimate } \\
\text { their distribution } \\
\text { properties (mean } \\
\text { and variance). }\end{array}$ \\
\hline $\begin{array}{l}\text { Multivariate } \\
\text { adaptive } \\
\text { regression } \\
\text { splines }\end{array}$ & $\begin{array}{l}\text { No specific SALM } \\
\text { objective. }\end{array}$ & $\begin{array}{l}\text { To estimate the form of the government's } \\
\text { objective function, once an SALM objective } \\
\text { has been established. The method could } \\
\text { also be used to determine the optimal } \\
\text { portfolio weights given different levels of the } \\
\text { objective function parameters (e.g., the risk } \\
\text { level). }\end{array}$ & $\begin{array}{l}\text { A specific functional form for the } \\
\text { objective function and the constraints; } \\
\text { constraints in the form of equalities. }\end{array}$ & $\begin{array}{l}\text { Time-series of } \\
\text { bond yields and } \\
\text { asset returns. }\end{array}$ \\
\hline $\begin{array}{l}\text { Dynamic } \\
\text { stochastic } \\
\text { optimization } \\
\text { model } \\
\text { (Claessens and } \\
\text { Kreuser, 2004) }\end{array}$ & $\begin{array}{l}\text { No specific SALM } \\
\text { objective. }\end{array}$ & $\begin{array}{l}\text { To determine the stochastic path of the } \\
\text { exogenous variables (interest and exchange } \\
\text { rates) and the optimal portfolio allocation, } \\
\text { once the SALM objective and the constraints } \\
\text { have been defined. Appropriate when there } \\
\text { is a need for flexibility of the SALM } \\
\text { objectives and constantly changing } \\
\text { strategies. }\end{array}$ & $\begin{array}{l}\text { Allows for low probability events with } \\
\text { large losses. The approach does not } \\
\text { require estimating a specific functional } \\
\text { form of the objective (utility function), } \\
\text { more akin to a revealed preferences } \\
\text { method. }\end{array}$ & \\
\hline $\begin{array}{l}\text { Contingent } \\
\text { claims analysis } \\
\text { (Gapen, et. }\end{array}$ & $\begin{array}{l}\text { No specific SALM } \\
\text { objective. }\end{array}$ & $\begin{array}{l}\text { To compute risk-adjusted mark- to-market } \\
\text { balance sheets, with a view to identify and } \\
\text { quantify credit risk, by combining liability- }\end{array}$ & $\begin{array}{l}\text { Sovereign's balance sheet consists of } \\
\text { sovereign assets, liabilities (mainly } \\
\text { external debt) and "equity" (junior }\end{array}$ & $\begin{array}{l}\text { Market information } \\
\text { about the value } \\
\text { and volatility of }\end{array}$ \\
\hline
\end{tabular}




\begin{tabular}{|l|l|l|l|l|}
\hline \multicolumn{1}{|c|}{ Approach } & SALM Objective & \multicolumn{1}{|c|}{ Use of the approach } & \multicolumn{1}{c|}{$\begin{array}{c}\text { Assumptions } \\
\text { Requirements }\end{array}$} \\
\hline $\begin{array}{l}\text { al., 2004 } \\
\text { and 2005) }\end{array}$ & & $\begin{array}{l}\text { related balance-sheet information with } \\
\text { current and forward looking financial market } \\
\text { prices. }\end{array}$ & $\begin{array}{l}\text { debt-domestic debt); normal } \\
\text { distribution of financial market prices; } \\
\text { appropriate benchmarking for external } \\
\text { risk indicators (e.g., CDS spreads). }\end{array}$ & $\begin{array}{l}\text { sovereign } \\
\text { liabilities of the } \\
\text { sovereign balance } \\
\text { sheet to derive the } \\
\text { sovereign asset } \\
\text { value and } \\
\text { corresponding } \\
\text { volatility. This info } \\
\text { is combined to } \\
\text { estimate risk } \\
\text { indications such } \\
\text { as the distance to } \\
\text { distress, default } \\
\text { probability and } \\
\text { credit spreads. }\end{array}$ \\
& & & \\
& & & \\
& & \\
\end{tabular}




\section{Institutional Setting for an Effective SALM}

\section{Interagency Coordination}

For an SALM framework to be effectively implemented there should be a high level of institutional coordination between entities that control or manage sovereign financial assets and sovereign liabilities. Ideally, coordination aspects should be given an appropriate legislative setting, as different institutional objectives and the needed degree of coordination between the entities involved may lead to institutional frictions. In case institutional constraints render an integrated asset and liability management strategy impossible to implement, more feasible second best options may take place.

Furthermore, in a stable macroeconomic environment with consistent fiscal and monetary policies, the role for the SALM could be simplified. A CaR approach-taking basic indicators such as GDP, the inflation and interest rates as given - may be sufficient to achieve the main sovereign objective. In such steady-state circumstances incorporating more sophisticated macro models and the central banks' balance sheet into the SALM approach has a low payoff - in terms of a set of new policy choices - and a high resource cost.

However, if the central bank conducts quasi-fiscal operations, it would be more prudent to manage a consolidated balance sheet including the central bank, because its financial viability may have sustainability implications for the sovereign. Such cases typically occur in the process of resolving financial crises. In practice, the liabilities that a central bank takes over should be recognized as contingent liabilities of the government. Hence, if the central bank is responsible for bailing-out financial institutions by issuing debt to recapitalize them, the central bank balance sheet should be managed jointly with the balance sheet of the government.

Furthermore, the issuance of central bank debt may raise governance issues since-unlike government debt - it is usually not subject to legislative approval (Stella and Lonnberg, 2007). In many countries, especially when the government does not have financing need, such debt is issued for monetary policy/sterilization purposes. Quite often the banking system is a captive investment base for such debt and its sustainability depends on the central bank's ability to make regular payments. Because of the systemic implications that might ultimately impact the government balance sheet, such central bank liabilities may have to be managed in a coordinated manner between the government and the central bank.

Similarly, coordination between the central bank and the government is warranted in the case of a (commodity-based) country with large fiscal surpluses that are being held at the central bank, particularly if the government owns a dominant share of the central bank liabilities. In this case the government balance sheet is directly affected by the risk management practices of the central bank. 


\section{Debt capital market development}

For an SALM approach to succeed in generating optimal outputs, a minimum development of domestic capital markets (principally, with regards to depth and liquidity) and financial intermediation (in particular, with regards to the investor base) is presumed. If constraints in capacity building and financial infrastructure exist, possible asset and/or debt allocations suggested by the SALM framework may not be feasible because domestic markets cannot accommodate them. This could especially be the case for countries that do not have adequately developed yield curves both in terms of benchmark issues and maturities, and their investor base is limited, possibly due to restrictive regulations or small population size of the country and limited growth prospects. These issues may significantly restrict the scope and usefulness of an SALM approach for many, especially developing, countries.

\section{SALM Framework ANd Select Country Practices}

In line with some of the theoretical considerations described above, this section provides a brief summary of the experience of a few selected countries. In particular, we provide an outline of the main elements of the SALM framework, including the structure of the sovereign balance sheet and SALM objectives, the risk management framework and indicators for modeling and monitoring risks on the sovereign balance sheet and the institutional framework within which countries conduct SALM (for technical aspects of SALM modeling, see also Appendix II).

\section{A. Sovereign Balance Sheet and SALM Objectives}

On the asset side, a typical sovereign balance sheet contains cash deposits, other special purpose funds - including pension reserve funds and sovereign wealth funds, foreign reserves, and receivables. On the liability side, the balance sheet contains the government debt stock, and in some cases, public guarantees and deposits by local authorities and commercial banks..

While closely linked, the objectives of managing assets and liabilities are seldom coordinated. The main objective of sovereign liability management is to ensure financing of the budget at the lowest possible cost subject to an acceptable level of risk. In contrast, the objectives of the sovereign asset management are to ensure that cash balances meet commitments and maximize the purchasing power of the long-term capital given moderate level of risk.

Some countries conduct a partially coordinated SALM. Typically, this involves integrated management of the net position on central government debt and cash reserves (Finland, Greece, and Turkey), thereby setting objectives and risk constraints only in account of these balance sheet items. In other cases, the allocation of assets between alternative portfolios and funds may take account of the government's broader priorities and objectives, but not specifically of balance sheet risks (Australia). In countries where government funds (e.g., pension funds) hold primarily government bonds, interest-rate risk is managed on a consolidated basis (Denmark). Coordination is also common when an increase in the international reserves requires debt issuance in foreign currencies, and the central bank may prepare a consolidated balance sheet (Hungary). Finally, the decision about the duration and currency composition of the international reserves may be based on the maturity structure and 
currency composition of the government foreign exchange liabilities, including off-balance sheet foreign exchange cash flows (Turkey). ${ }^{16}$

\section{B. Risk Management Framework}

As the SALM objectives are frequently specified based on a narrow set of the balance sheet items - e.g., net central government debt and cash reserves, the risk management considerations from an asset management perspective naturally involve minimizing liquidity and credit risk and, in some cases, interest rate risk. From a liability management perspective, considerations for minimizing interest rate risk, refinancing risk, and currency risk prevail among debt managers.

Duration and modified duration are used commonly in both asset and liability management. VaR is used more commonly by asset managers, while CaR by liability (debt) managers (see Section II. C and Appendix I). Asset managers also use scenario analysis and stress tests more often than liability managers; and counterparty limits are common to prevent credit risk by asset managers. With respect to liability management, ratio analysis — and in particular the refixing ratio - is commonly used to monitor risks.

Asset and liability managers rarely produce in-house forecasts for the exchange rates, interest rates and inflation. When such forecasts are made in-house, they are typically based on historical data using econometric models or are derived from forward curves. Forecast data are typically received from national statistical agencies or specialized units in the ministry of finance or the central bank.

\section{The Institutional Framework}

The sovereign assets and liabilities are managed by a debt management office, the central bank, or statutory agencies charged with the management of specific funds.

Given the prevailing fragmentation in the operational management of sovereign assets and liabilities, coordination between various institutions involved in SALM is not common. In the most integrated case, decision making authority for both assets and liabilities is assigned to one agency or ministry — e.g., the ministry of finance — who delegates responsibilities for dayto-day management - e.g., to the central bank - and coordinates the planning and execution of the borrowing and investing programs (Canada). In other cases, the mandates of the agencies in charge of SALM may be set following coordination or a delegation by a responsible ministry - treasury or the ministry of finance (Australia). Another more common coordination mechanism is instituting regular meetings between the agencies involved in SALM (Hungary, Canada).

\footnotetext{
${ }^{16}$ Debt management tends to have a much longer horizon than asset/reserve management, as another argument that complicates SALM.
} 
Further, a few countries who have established SWFs to preserve financial assets generated from natural resource endowments or continued budget surpluses and privatization proceeds, maintain their assets and liabilities on the central government's balance sheets. These countries have also issued debt, albeit at low levels. This has helped maintain effectively functioning financial markets with important consequences for the level of interest rates (Australia) and the effectiveness of liquidity management (Norway).

\section{CONCLUding Remarks}

Admittedly, going from managing the treasury function of a government to SALM is a long way. However, some countries have already embarked on some form of coordinated SALM, which typically involved integrated management of the net position on central government debt and other financial liabilities, and cash reserves. In adopting a more comprehensive and integrated sovereign asset and liability management framework, a joint analysis of the characteristics of financial assets and liabilities on the sovereign balance sheet allows decision makers to take into account more fully the interrelationships and correlations among sources of risks when formulating strategies and policies. The SALM framework also provides an appropriate setting for a comprehensive sovereign portfolio stress testing. This should allow countries to optimally manage their sovereign debt and asset portfolios and attain a desired level of balance sheet risk exposure in a prudent and cost effective manner.

A wider SALM approach in managing sovereign risks will require a consolidated view of the sovereign balance sheet and its risk exposures, as well as coordinated decisions on the appropriate portfolio strategies to be adopted to manage that risk effectively. Nevertheless, the design of an effective framework that can be operationalized is a crucial issue, while successful operationalization of such a framework may entail institutional challenges, though not insurmountable. A precondition for developing an appropriate SALM framework is having clarity about macroeconomic policy goals. Also, given the high level of uncertainty, risk assessment should play a central role in informing the SALM strategy. Such assessment may require elaboration of alternative scenarios that encompass short- and long-term costs and stress test for various macroeconomic shocks. Potential contingent liabilities in a sovereign balance sheet should also be analyzed, using, for example, quantitative methods such as the CCA framework. Further, information about the risk associated with the management of the sovereign balance sheet need to be published; as transparency and accountability help public stakeholders better understand and maintain confidence in SALM. However, involvement of multiple institutions that comprise the sovereign balance sheet could blur accountability.

From an institutional point of view, combining the management of sovereign assets and liabilities under one framework may not always be desirable or feasible. As long as the roles, objectives and resources of institutions involved in SALM are clearly defined and consistent, an SALM approach could ensure appropriate coordination in the management of assets and liabilities across institutions while maintaining the independence of each institution. However, depending on a country's structural and institutional conditions, an SALM approach could, , help better analyze and manage a country's sovereign balance sheet and comprehensively review possible policy interconnections taking into account identified risks, mitigate potential distortionary spillovers, and better prepare for systemic events. 


\section{REFERENCES}

Abutaleb, Ahmed and Michael G. Papaioannou, 2006, Stochastic Control for the Estimation of Time-Varying-Parameter, mimeograph, (Washington, DC: International Monetary Fund).

Au-Yeung, Wilson, Jason McDonald, and Amanda Sayegh, 2006, "Australian Government Balance Sheet Management," NBER Working Papers 12302, (Cambridge, MA: National Bureau of Economic Research).

Barro, Robert J., 1995, “Optimal Debt Management,” NBER Working Papers 5327, (Cambridge, MA: National Bureau of Economic Research).

Bergstrom, P., A, Holmlund and S. Lindberg, 2002, “The SNDO's Simulation Model for Government Debt Analysis," Mimeograph, The Swedish National Debt Office.

Bodie, Zvi and Marie Briere, 2011, "Sovereign Wealth and Risk Management," Working Paper Amundi 6, May 2011.

Bohn, Henning, 1990, “Tax Smoothing with Financial Instruments," The American Economic Review, Vol.80, No.5, pp. 1217-1230.

Bohn, Henning, 2002, “Government Asset and Liability Management in an Era of Vanishing Public Debt," Journal of Money, Credit, and Banking, 34 (August), pp. 887-933.

Bolder, David Jamieson, 2002, “Towards a More Complete Debt Strategy Simulation Framework," Bank of Canada Working Paper 2002-13, (Ottawa, Ontario, Canada: Bank of Canada).

Bolder, David Jamieson and Tiago Rubin, 2007, "Optimization in a Simulation Setting: Use of Function Approximation in Debt Strategy Analysis," Bank of Canada Working Paper 2007-13, (Ottawa, Ontario, Canada: Bank of Canada).

Bussière, Matthieu and Christian Mulder, 1999, "External Vulnerability in Emerging market Economies: The Trade-Off between Fundamentals and Liquidity," IMF Working Paper WP/99/88, (Washington, DC: International Monetary Fund).

Cassard, Marcel and David Folkerts-Landau, 2000, Sovereign Assets and Liabilities Management, Proceedings of a Conference in Hong Kong, SAR, (Washington, DC: International Monetary Fund).

Cabral, Rodrigo, Mariana Lopes, William Baghdassarian, Luiz Fernando Alves, Pedro Junior, and Antonio dos Santos, 2008, "A Benchmark for Public Debt: The Brazilian Case," Public Debt Strategic Planning Department, (Brasilia, Brazil: National Treasury of Brazil).

Center for Research into Economics and Finance in South Africa, 1995, "Sovereign Asset and Liability Management: A Debt Management Office," Quarterly Review, April 1995, pp 14-19. 
Chan, K.C., G. Andrew Karolyi, Francis A. Longstaff, and Anthony B. Sanders, 1992, "An Empirical Comparison of Alternative Models of the Short-Term Interest Rates," The Journal of Finance, Vol. 47, No. 3 (July), pp. 1209-27.

Claessens, Stijn and Jerome Kreuser, 2004, "A Framework for Strategic Foreign Reserves Risk Management," in Risk Management for Central Bank Foreign Reserves, (Frankfurt am Main, Germany: European Central Bank).

Claessens, Stijn, 2005, "Taking Stock of Risk Management Techniques for Sovereigns,” World Bank Policy Research Working Paper WPS 3570.

Claessens, Stijn and Jerome Kreuser, 2007. "Strategic Foreign Reserves Risk Management: Analytical Framework," Annuals of Operations Research, Springer Netherlands, Vol. 152, No. 1 (July), pp. 79-113.

Cox, John C., Jonathan E. Ingersoll, and Stephen A. Ross, 1985, "A Theory of the Term Structure of Interest Rates," Econometrica, Vol. 53, No. 2, pp. 385-407.

Crouhy, Michel, Dan Galai, and Robert Mark, 2000, "A Comparative Analysis of Current Credit Risk Models," Journal of Banking and Finance, Vol. 24, pp. 59-117.

Currie, Elizabeth, and Antonio Velandia, 2002, Risk Management of Contingent Liabilities within a Sovereign Asset-Liability Framework, (Washington: World Bank).

Daniel, James A., 2001, "Hedging Government Oil Price Risk," IMF Working Paper WP/01/185, (Washington, DC: International Monetary Fund).

Danmarks Nationalbank, 2000, Danish Government Borrowing and Debt 2000, (Copenhagen, Denmark).

Das, Udaibir S., 2011, "Managing Sovereign Risk - An Integrated Approach for Sovereign Assets and Liabilities," in Growth and Finance: Essays in Honour of C. Rangarajan, Sameer Kochhar (ed), (New Delhi, India: Academic Foundation).

de Montpellier, Louis, 2000, "Public Debt Management Strategy: Belgium's Experience," in Marcel Cassard and David Folkerts-Landau (eds.) Sovereign Assets and Liabilities Management, Chapter 8, (Washington, DC: International Monetary Fund).

Diebold, Francis X. and Canlin Li, 2006, "Forecasting the Term Structure of Government Bond Yields," Journal of Econometrics, Vol. 130, pp. 337-364

Dornbusch, Rudiger, 1983, "Real Interest Rates, Home Goods, and Optimal External Borrowing," Journal of Political Economy, Vol. 91, No. 1, pp. 141-53.

Duffie, Darrell, and Rui Kan, 1996, "A Yield-Factor Model of Interest Rates," Mathematical Finance, Vol. 6, No. 4 (October), pp. 379-406. 
Eichengreen, Barry and Ricardo Hausmann, 1999, "Exchange Rates and Financial Fragility," NBER Working Papers No.7418, (Cambridge, MA: National Bureau of Economic Research).

Fisher, Stephen and Min C. Lie, 2004, “Asset Allocation for Central Banks Optimally Combining Liquidity, Duration, Currency and Nongovernment Risk", in Risk Management for Central Bank Foreign Reserves, ed. by Carlos Bernadell, Pierre Cardon, Joachim Coche, Francis X. Diebold and Simone Manganelli, (Frankfurt am Main, Germany: European Central Bank).

Gapen, Michael T, Dale F. Gray, Cheng Hoon Lim, and Yingbin Xiao, 2004, "The Contingent Claims Approach to Corporate Vulnerability Analysis: Estimating Default Risk and Economy-wide Risk Transfer," IMF Working Paper WP/04/121, (Washington, DC: International Monetary Fund).

Gapen, Michael T, Dale F. Gray, Cheng Hoon Lim, and Yingbin Xiao, 2005, "Measuring and Analyzing Sovereign Risk with Contingent Claims," IMF Working Paper WP/05/155, (Washington, DC: International Monetary Fund).

Gong, Gang and Willi Semmier, 2006, Stochastic Dynamic Macroeconomics: Theory and Empirical Evidence, (Oxford: Oxford University Press).

Gray, Dale F. and Matthew T. Jones, 2006, The Contingent Claim Approach to Measuring Sovereign Risk in Indonesia, Selected Issues (Washington, DC: International Monetary Fund).

Gray, Dale F., Robert C. Merton, and Zvi Bodie, 2006, “A New Framework for Analyzing and Managing Macrofinancial Risks of an Economy," National Bureau of Economic Research Working Paper 12637, (Cambridge, MA: National Bureau of Economic Research). Wiley).

Gray, Dale F., Samuel W. Malone, 2008, Macrofinancial Risk Analysis, (New York:

Grimes, Arthur, 2001, "Crown Financial Asset Management: Objectives and Practice," New Zealand Treasury Working Paper 01/12.

Hansen, Eric, 2003, "Objectives, Targets and Instruments for Crown Financial Policy," New Zealand Treasury Working Paper 03/21.

Heath, David, Robert Jarrow, and Andrew Morton, 1992, "Bond Pricing and the Term Structure of Interest Rates: A New Methodology," Econometrica, Vol. 60, No. 1, pp. 77-105.

Horman, Greg, 2002, Sovereign Asset-Liability Management in New Zealand, (Wellington, New Zealand). Available via the Internet at: http://www.nzdmo.govt.nz/publications/sovereignalm/sov-alm-nz.pdf. 
Hull, John, 2011, Options, Futures, and Other Derivatives, eighth edition (Upper Saddle River, NJ: Prentice Hall).

Hull, John, and Alan White, 1994a, "Numerical Procedures for Implementing Term Structure Models I: Single Factor Models," Journal of Derivatives, Vol. 2, No.1, pp. 7-16.

Hull, John, and Alan White, 1994b, "Numerical Procedures for Implementing Term Structure Models II: Two Factor Models," Journal of Derivatives, Vol. 2, No. 1, pp. 37-48.

International Monetary Fund and the World Bank, 2001, Guidelines for Public Debt Management, (Washington: International Monetary Fund and The World Bank).

International Monetary Fund, 2001, Guidelines for Foreign Exchange Reserve Management, (Washington: International Monetary Fund).

International Monetary Fund, 2004, Liquidity Management, Policy Development and Review Department, April 23 (SM/04/149), (Washington: International Monetary Fund).

International Monetary Fund, 2007, Financial Market Turbulence: Causes, Consequences, and Policies, Global Financial Stability Report (Washington: International Monetary Fund).

International Monetary Fund, 2011, Assessing Reserve Adequacy, (Washington: International Monetary Fund).

International Monetary Fund, 2012, Macroeconomic Policy Frameworks for ResourceRich Developing Countries, August 15 (Washington: International Monetary Fund).

Jensen, Ove Sten and Morten Kjaergaard, 2005, "Market Risk Management of Public Debt," in Proceedings of the First Annual Meeting of Latin American and Caribbean Public Debt Management Specialists, March 17-19, 2005, Inter-American Development Bank, pp.133-140.

Kall, Peter and Janos Mayer, 2005, Stochastic Linear Programming: Models, Theory, and Computation, Springer's International Series in Operation s Research and Management Science, (New York: Kluwer Academic Publishers).

Kreuser, Jerome L., 2002, The Rapid Implementation of Asset/Liability Models for Sovereign Risk Management, in Programming Languages in Computational Economics and Finance, ed. by S. Nielsen, (Dordrecht, The Netherlands: Kluwer Academic Publishers).

Leigh, Daniel and Jan-Peter Olters, 2006, "Natural-Resource Depletion, Habit Formation, and Sustainable Fiscal Policy: Lessons from Gabon," IMF Working Paper WP/06/193, (Washington, DC: International Monetary Fund).

Lu, Yinqiu, Michael Papaioannou, and Iva Petrova, 2007, "Sovereign Asset and Liability Management," IMF $7^{\text {th }}$ Debt Managers' Forum, November 5-6, 2007, (Washington, DC: International Monetary Fund). 
pp. 77-91.

Markowitz, Harry, 1952, "Portfolio Selection," The Journal of Finance, Vol. 7, No. 1,

Marti, Kurt, Yuri Ermoliev, and George Pflug, eds., 2004, Dynamic Stochastic Optimization, Lecture Notes in Economics and Mathematical Systems, 532, Berlin: Springer Verlag.

Merton, Robert C., 2007, "Observations on Sovereign Wealth Fund, Reserve and Debt Management: A Country Risk Management Perspective," Luncheon Address at the First IMF Annual Roundtable of Sovereign Asset and Reserve Managers, November 15-16.

Missale, Alessandro, 1997, "Managing the Public Debt: Optimal Taxation Approach," Journal of Economic Surveys, 11(3), pp. 235-265.

Missale, Alessandro, 2000, "Optimal Debt Management with a Stability and Growth Pact.” Innocenzo Gasparini Institute for Economic Research Working Papers No 166, Bocconi University. Available via the Internet at: http://econpapers.repec.org/paper/igiigierp/166.htm

Mundell, Robert A., 1973, "Uncommon Arguments for Common Currencies," in Harry G. Johnson and Alexander K. Swoboda, eds., The Economics of Common Currencies, (Cambridge, MA: Harvard University Press), pp. 114-32.

Nelson, Charles R. and Andrew F. Siegel, 1987, "Parsimonious Modeling of Yield Curves," The Journal of Business, Vol. 60, No. 4, pp. 473-489.

Nugée, John, 2000, Foreign Exchange Reserves Management, Handbook in Central Banking No 19, Centre for Central banking Studies, (London: Bank of England).

Papaioannou, Michael G., 1993, The Role of the SDR in the Diversification of Exchange Reserves, mimeograph, (March), (Washington, DC: International Monetary Fund).

Papaioannou, Michael G., 2006, “A Primer for Risk Measurement of Bonded Debt from the Perspective of a Sovereign Debt Manager," IMF Working Paper, WP/06/195, (Washington, DC: International Monetary Fund).

Papaioannou, Michael G., 2009, "Exchange Rate Risk Measurement and Management: Issues and Approaches for Public Debt Managers," South Eastern Europe Journal of Economics, Vol. 7, No. 1, Spring, pp. 7-34.

Papaioannou, Michael G., and Marcos Souto, 2007, A Toolkit to Measure the Market and Credit Risk of a Portfolio of Government Bond Securities - USER'S GUIDE, mimeograph, (May), (Washington, DC: International Monetary Fund).

Pick, Andreas and Myrvin Anthony, 2006, "A Simulation Model for the Analysis of the UK's Sovereign Debt Strategy," UK Debt Management Office Research Paper, August. 
Piga, Gustavo, 2001, Derivatives and Public Debt Management, International Securities Market Association (Zurich).

Réz, András, 2007, Public debt management and Asset-liability management - the case of Hungary, Available via the Internet at: $\underline{w w w . u n . o r g} / \mathrm{esa} / \mathrm{ffd} / \mathrm{Multi}-$ StakeholderConsultations/FFDO/SovereignDebt/andr\%E1s\%20r\%E9z.pdf.

Risbjerg, Lars and Anders Holmlund, 2005. "Analytical Framework for Debt and Risk Management," in Advances in Risk Management of Government Debt, (Paris, France: OECD).

Rosenberg, Christoph, Ioannis Halikias, Brett House, Christian Keller, Jens Nystedt, Alex Pitt, and Brad Setser, 2005. "Debt-related Vulnerabilities and Financial Crises: An Application of the Balance Sheet Approach to Emerging market countries," IMF Occasional Paper 240, (Washington DC: International Monetary Fund).

Ruszczynski, Andrzej and Alexander Shapiro, eds, 2003, Stochastic Programming, Handbooks in operations Research and Management Science, Vol. 10, (Amsterdam, Holland: Elsevier).

Silva, Anderson Caputo, 2005, "Public Debt Risk Management," in Proceedings of the First Annual Meeting of Latin American and Caribbean Public Debt Management Specialists, March 17-19, 2005, Inter-American Development Bank, pp.161-175.

Shapiro, Alexander, Darinka Dentcheva, and Andrzej Ruszczynski, 2009, Lectures on Stochastic Programming; Modeling and Tehory, MPS-SIAM Book Series on Optimization 9, Philadelphia, PA: Society for Industrial and Applied Mathematics (SIAM).

Stella, Peter and Ake Lonnberg, 2007, "Issues in Central Bank Finance and Independence," IMF Working Paper, WP/08/37, (Washington DC: International Monetary Fund).

Traa, Bob and Alina Carare, 2007, "A Government's Net Worth," Finance and Development, June 2007, Volume 44, Number 2, (Washington D.C.: International Monetary Fund ).

Topaloglou, Nikolaos, Hercules Vladimirou and Stavros A. Zenios, 2008, “A Dynamic Stochastic Programming Model for International Portfolio Management," European Journal of Operational Research, Vol. 185, No. 3 (March), pp. 1501-1524.

Wallace, Stein W. and William T. Ziemba, eds, 2005, Applications of Stochastic Programming, MPS-SIAM Book Series on Optimization 5, Philadelphia, PA: Society for Industrial and Applied Mathematics (SIAM).

Zacho, Lisbeth Stausholm, 2006, Managing Sovereign Assets and Liabilities, in Government Debt Management: New Trends and Challenges, Mike Williams (ed.), (London, UK: Central Banking Publications), pp. 49-60. 


\section{APPENDiX I: SELECT SALM METHODOLOGIES}

\section{Mean-variance approach}

The mean-variance approach, based on Markowitz (1952), is often used by central banks to determine a strategic asset allocation of international reserves. The approach assumes that the government wants to maximize the return of its portfolio subject to a prespecified level of risk. In practice, this approach allows a central bank to model and determine a portfolio that preserves the value and liquidity of the sovereign assets and restricts investments to securities with specific characteristics regarding currency, maturity and credit rating. Following Fisher and Lie (2004) and Papaioannou (1993), the approach — in a dynamic framework - could be expressed in a stylized form by the following maximization problem:

$$
\max _{\omega_{i}, \omega_{f}} E_{t}\left[R_{t+1}\right]=\sum_{i=1}^{I} \omega_{i, t} E_{t}\left(r_{i, t+1}\right)+\omega_{f, t} r_{f, t+1}
$$

Subject to:

$$
\begin{aligned}
& W_{t} V_{t} W_{t} \leq \sigma^{2} \\
& \sum_{i=1}^{I} \omega_{i, t}+\omega_{f, t}=1, \forall t \\
& \omega_{i} \geq 0, \forall t \text { and } \forall i
\end{aligned}
$$

where:

$R_{t}$ is the gross return on the sovereign portfolio of reserve assets in period $t$;

$r_{f}$ is the return on the risk-free (or liquid) asset, typically a US Treasury security;

$E_{t}\left(r_{i, t+1}\right)$ is the expected in period $t$ next-period return on asset $i$;

$\omega_{i, t}$ is the weight of asset $i$ in the portfolio in period $t$;

$W_{t}$ is a vector of portfolio weights;

$V_{t}$ is a covariance matrix;

$\sigma^{2}$ is an upper limit on the portfolio variance.

A number of additional constraints could be imposed in this framework, including: (i) a minimum share of the risk-free (liquid) asset in accordance with a specific reserve adequacy level; (ii) maximum duration of the portfolio; (iii) maximum exposure to each currency; (iv) 
upper limits on the weighted downgrade and default probabilities of the portfolio; and (iv) upper limits on transaction costs.

In general, in a stylized form of the mean-variance approach, the government assumes a certain risk level, which is not necessarily zero (i.e., risk averse). The variance of the portfolio is not minimized, but there is a maximum level of risk-perhaps expressed in relevant investment guidelines - that the government is willing to tolerate. ${ }^{17}$

\section{Value-at-Risk (VaR) method}

The VaR method is used to calculate a "worst case" loss that can occur in a sovereign's (asset and/or liability) portfolio value during severe, adverse market fluctuations. Typically, a severe loss is often termed as a loss that has a 1 percent probability of occurring over a certain horizon. If we are measuring daily losses, this is equivalent to stating that, on average, a loss worse than the calculated VaR will be incurred on two to three days per year. The VaR level is calculated by using the current holdings in a portfolio and an estimate of the probability distribution of the price changes over the next investment period (based on the distribution of historical price changes in assets or risk factors - over the last few weeks, months or years). From the probability distribution over the next period we can infer about the confidence level for, say, the 99-percentile loss.

A common assumption is that movements in the markets have a normal probability distribution, implying that there is a 1 percent chance that losses will be greater than 2.33 standard deviations. Then, the 99 percent VaR for a portfolio can be defined as:

$$
\operatorname{VaR}_{T}=2.33 \times \sigma_{T}
$$

where

$\sigma$ is the standard deviation of the portfolio's value;

$T$ is the time period over which the standard deviation of returns is calculated.

The VaR can be calculated for any time horizon. When the VaR is used to refer to associated potential losses, a monthly or yearly horizon is employed. ${ }^{18}$ Also, the VaR probability may be higher or lower than 1 percent. A common alternative is to set the tail probability at 2.5 percent, which implies 1.96 standard deviations. There are three commonly used methods

\footnotetext{
${ }^{17}$ This approach is similar to Dornbusch's (1983) utility maximization by allocating a fixed level of wealth among a specified number of securities with random returns. As with methods applied to find an optimal government debt portfolio, the mean-variance approach is consistent with a government's main objective of maximizing social welfare by selecting an optimal portfolio of sovereign assets.

${ }^{18}$ To calculate VaR for potential losses over multiple days, an approximation to the multiday VaR is $V a R_{T}=V a R_{1} \times \sqrt{T}$, assuming that (i) changes in market factors are normally distributed; (ii) the one-day $\mathrm{VaR}$ is constant over the time period; and (iii) there is no serial correlation.
} 
to calculate VaR: (i) parametric VaR; (ii) historical simulation; and (iii) Monte Carlo simulation (Papaioannou, 2006 and 2009).

\section{Cost-at-Risk (CaR) method}

In a CaR framework, the debt-servicing costs and associated risks for various financing strategies and a given debt profile are calculated based on a continuum of changes in macroeconomic variables (e.g., the term structure of interest rates and exchange rates), using stochastic simulation techniques. The distribution of the debt level is determined at the end of a given time period. Expected costs are usually measured as the average values from the distribution of debt-servicing costs. The absolute CaR is often measured as the $99^{\text {th }}$ percentile of the debt-servicing costs, while the relative $\mathrm{CaR}$ is measured as the difference between the $99^{\text {th }}$ percentile and the expected costs.

The combinations of cost and risk for the different financing strategies are, then, plotted on a cost-risk plane. The set of efficient strategies, defined as the ones that generate the minimal cost at a given level of risk, determine the efficient frontier. Subsequently, for a prespecified value of a risk level, the optimal cost-risk combination is determined by the efficient frontier. This optimal cost-risk combination constitutes the optimal strategy.

\section{Multivariate Adaptive Regression Splines (MARS) method}

The MARS method allows the estimation of the objective function of the government, thus providing computational completeness to the SALM problem. While the SALM objective may be clearly stated, optimization of this objective crucially depends on the specification of the government's objective function. Simulation estimates based on various methods show that MARS outperforms other methods, particularly when the objective function is highly dimensional and nonlinear and there is a lack of a large number of observations (Bolder and Rubin, 2007). ${ }^{19}$ Thus, given uncertainty about the complexity of the government's objective function, the MARS method allows significant flexibility in its estimation.

MARS has helped to illustrate empirically well-known theoretical statements. Simulations using MARS exemplify how the optimal debt portfolio could change depending on the government's objective. ${ }^{20}$ Given a certain amount of debt stock, permissible financing options - government securities with maturities of three months, one year, and five yearsand a certain macroeconomic environment, it can be shown that:

\footnotetext{
${ }^{19}$ In their simulations, Bolder and Rubin (2007) compare estimates of the ordinary least squares (OLS), nonparametric kernel regression (NKR), the projection pursuit regression (PPR), and MARS. They find that the goodness of fit of the NKR and PPR methods deteriorate quickly for even simple parabolic functions as their dimension increases. MARS and OLS perform well when using conic-cosine functions and MARS outperforms OLS when fitting more complex functions, such as the Rosenbrock function.

${ }^{20}$ Bolder and Rubin (2007) have performed such simulations with data for Canada.
} 
- $\quad$ The optimal debt strategy gives a higher weight to shorter-term maturities - up to one year-when the objective of the government is to minimize the cost of debt service. The weight of longer-term maturities increases if the government faces a risk constraint or maximizes a utility function which is risk averse. The method allows quantifying the increase in the debt service cost, depending on the stringency of the risk constraint. It also illustrates the increase in the debt service cost when other constraints are imposed on the government financing strategy, such as limits on the share of specific instruments due to possible underdevelopment of these segments of the government debt market;

- The share of longer-term maturities in the optimal debt portfolio increases when the government's objective is to minimize the cost of debt service, while minimizing the probability of a budget deficit. Moreover, the higher weight the government places on reducing the probability of a budget deficit, the higher the optimal share of longerterm debt. This exercise illustrates the practical similarity between an objective of welfare maximization and budget smoothing; and

- $\quad$ The optimal debt portfolio contains a high share of short-term securities if the government is highly risk averse. As expected, the share of long-term maturities increases with increases in the parameter measuring risk aversion; however, for a very high value of risk aversion, the government will choose a combination of only threemonth and five-year securities. The reason is that a highly risk averse government places great weight both on the cost of debt service and on its volatility, which renders a polar portfolio as the most preferred to any other.

MARS can also be used to simulate the impact of changes in macroeconomic variables on the optimal SALM strategy. Admittedly however, the method takes these macroeconomic variables as given, which requires the use of separate techniques to model their path. Such modeling could increase enormously the space of possible optimal strategies. In addition, data requirements in applying MARS remain a challenge.

\section{Dynamic Stochastic Optimization Model}

Dynamic stochastic optimization models cover stochastic processes in which time plays an essential role (Ruszczynski and Shapiro, 2003; Marti et al., 2004; Kall and Mayer, 2005). The emphasis is often on Markov decision processes (also known as probabilistic dynamic programming) and the optimization of stochastic models (Wallace and Ziemba, 2005; Shapiro et al., 2009). In particular, stocks and flows are identified in sovereign liabilities and asset models with expected present values determining trade-offs in a probabilistic dynamic (i.e., time-varying) set up (Gong and Semmier, 2006; Topaloglou, et al., 2008).

In this context, it is essential that a sovereign adopts a dynamic approach in adjusting its assets and liabilities. In particular, Claessens and Kreuser $(2004,2007)$ propose the following ALM analytical framework, which is based on three main steps: 
- Generate sparse trees of stochastic variables. The variables that define the future states of the world include (i) exogenous variables, e.g., interest rates, exchange rates, GDP, fiscal deficits, current account deficits, and other variables that are to be stochastically estimated (bond prices and commodity prices, as well as rare events that may trigger contingent liabilities, e.g., a banking system crisis); and (ii) endogenous or "decision variables," such as the levels of foreign exchange reserves and debt, the maturity structure of reserves and debt, the reserve currency shares, etc.

The task is then to generate a set of scenarios of possible realizations for the exogenous variables using multi-factor stochastic partial differential equations, such as: ${ }^{21}$

$$
d s(t) / s(t)=\mu(s, t) d t+\sum b(s t, t) \sigma(s, t) d \varpi(t)
$$

The parameters $(\mu, b, \sigma)$ of these equations can be estimated from historical data (Abutaleb and Papaioannou, 2006). This structure allows the estimation of most variables as rates of return, consistently with many stochastic estimations;

- Formulate and solve a dynamic stochastic optimization model. The second step is to build a model to derive the decision variables, with the model being defined independently of the stochastic processes, the tree, or the events on the tree, The separation of the stochastic processes from the model formulation allows changes to constraints or objectives and modifications of the tree, e.g., making it larger or introducing stress tests, without affecting the tree or the model, respectively.

The set of events that occur for each time period and the events that precede any event in any time period need to be defined. Decision variables are then defined for each event with respect to the levels of assets, liabilities, currencies, and other investment assets, including derivatives. Also, decision variables may be specified to allow short selling, the specification of transaction costs, spreads, and limits to be individually imposed in order to enhance the stability of the model. The selection of what decision variables will be used depends on the specific issues to be analyzed and objectives pursued. Since the model intends to provide insights for decision makers, assets in the portfolio are usually defined in terms of broad classes, such as short-, medium-, and long-duration assets, or segments of different currency clusters, rather than at the level of individual assets or currencies.

- Estimate density functions of outcomes from the model. Assuming that the objective is to maximize the expected return at the end of the investment horizon, the model can be solved and the density functions for all factors under consideration can be estimated using, e.g., maximum likelihood methods.

\footnotetext{
${ }^{21}$ This representation underlies commonly used multi-factor models, including those with mean reversion, such as the Hull and White, and Heath, Jarrow, and Morton (see Appendix II).
} 
In general, policy makers have preferences on the shapes of the density functions. These preferences can be defined formally as objective functions, with or without constraints. That is, preferences "shape" the preferred density functions of the outcomes. The advantages of more explicit "shaping" is that, unlike what is often done in objective functions, it is not needed to specify or estimate some parameters, such as utility preferences. Rather, it is allowed that policy makers review the actual density functions obtained and then state their preferences as criteria related to concepts, such as "a less fat left tail" or "less probability mass in a certain region." In essence, this approach allows asset and liability allocations to be determined on the basis of analyzing density functions resulting from various combinations of techniques.

\section{Contingent Claims Analysis (CCA) approach}

The application of the CCA requires observable market information about the value and volatility of sovereign liabilities to derive the value of non-observable quantities, such as the sovereign asset value and corresponding volatility (Bodie and Briere, 2011 and Gray et al., 2006). ${ }^{22}$ This information is used to estimate credit risk indicators, such as the distance-todistress, default probabilities and credit spreads. In order to derive default probabilities, assumptions must be made about the seniority structure of the sovereign's liabilities. External debt is generally considered the most senior liability, while domestic debt and base money represent junior liability of the sovereign balance sheet and can be viewed as a contingent claim on the residual value of sovereign assets (Table 1$).{ }^{23}$ Default occurs when the value of implied assets falls below a distress barrier (Figure 2). ${ }^{24}$ Distance-to-distress is the difference between the asset value and the distress barrier, scaled by the asset volatility, while the area of the distribution that falls below the distress barrier represents the sovereign's default probability.

\footnotetext{
${ }^{22}$ This estimation uses the simple Black and Scholes option formula.

${ }^{23}$ External versus domestic debt is defined on the basis of the residency of the holder of debt, and not of the currency denomination. Also, the CCA model is flexible enough to accommodate any seniority structure, as long as the distress barrier is estimated appropriately. It can also be used to model credit risk on local-currency debt.

${ }^{24}$ Following Moody's KMV, the distress barrier (DB) for senior debt is defined as short-term debt (maturity $\leq 1$ year), plus interest payments due within a year and a fraction (usually a number between 0.5 and 0.8 ) of longterm debt (see Hull, 2011 and Crouhy et al., 2000).
} 
Figure 2. Overview of CCA for the Sovereign ${ }^{1}$

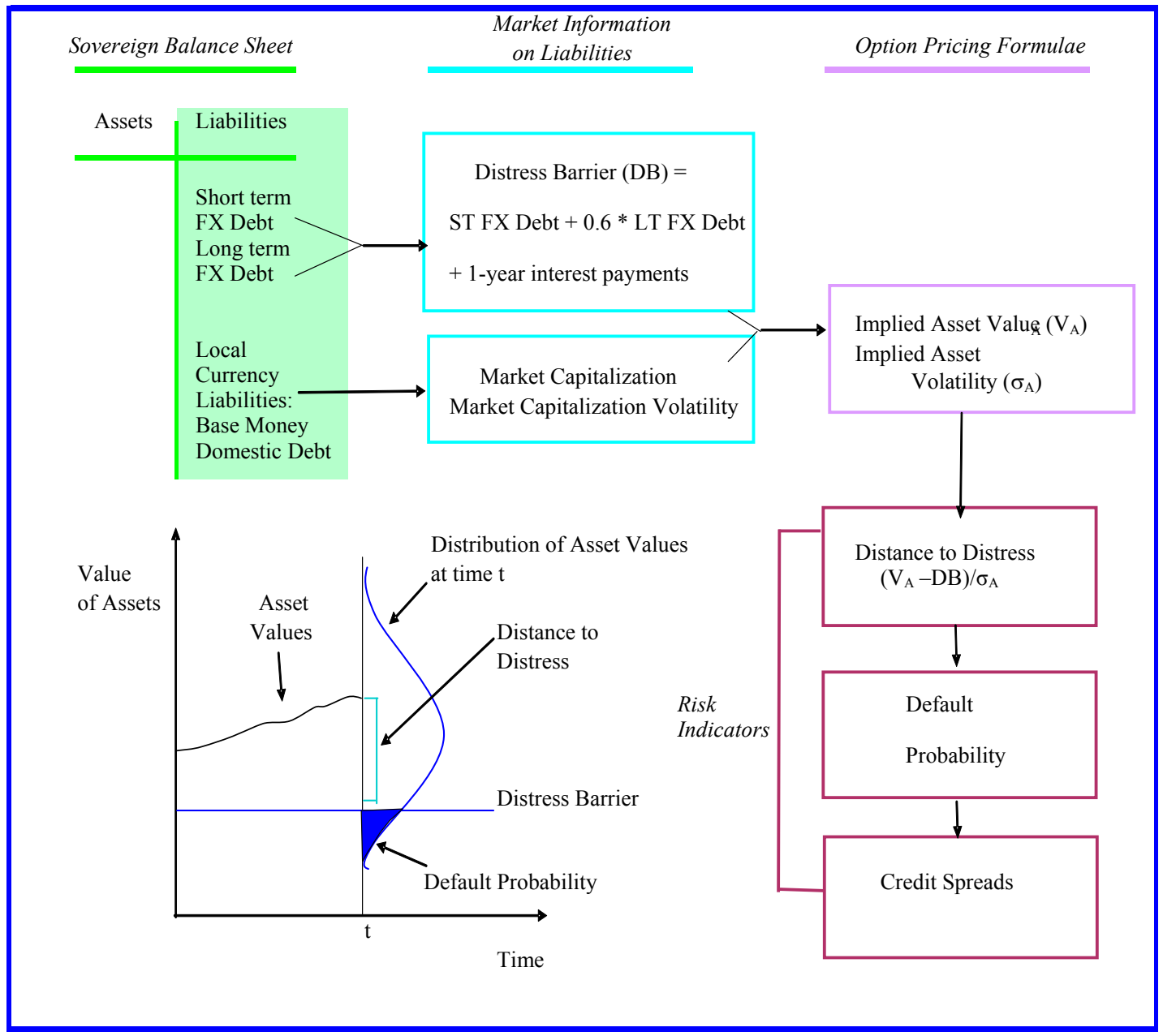

${ }^{1}$ Souce: Gray and Jones (2006).

Following Gray and Malone (2008), the distress barrier (DB) is defined as:

$$
D B=S T D+\alpha \cdot L T D+I P T M
$$

where STD is the short-term external debt (maturity $\leq 1$ year), LTD is the long-term external debt (maturity $>1$ year), $\alpha$ is a parameter between 0 and 1 (usually around 0.5 ), and IPTM corresponds to the interest payments on external debt due in the first year. Then, sovereign assets and volatilities can be estimated through:

$$
V_{\text {Sovs }} \sigma_{\text {Sovs }}=L C L_{\mathrm{s}} \sigma_{L C L S} N\left(d_{1}\right)
$$

and,

$$
L C L_{\mathrm{S}}=V_{\mathrm{Sovs}} \mathrm{N}\left(d_{1}\right)-D_{f, s} e^{-r_{f} T} \mathrm{~N}\left(d_{2}\right)
$$


where $V_{\text {Sovs }}$ and $\sigma_{\text {Sovs }}$ are the implied values of sovereign asset and volatility (in foreign currency terms), respectively, $L C L_{s}$ is the value of base money plus domestic debt (in foreign currency terms), $\sigma_{L C L S}$ is the volatility of $L C L_{\S}$ (in foreign currency terms), $D_{f, \$}$ is the distress barrier (in foreign currency terms), $r_{f}$ is the (foreign) risk-free interest rate - assumed constant, and $d_{1}$ and $d_{2}$ are the terms from the Black and Scholes option formula as defined below:

$$
d_{1}=\frac{\ln \left(\frac{V_{\text {Sovs }}}{D_{f, s}}\right)+\left(r_{f}+\frac{1}{2} \sigma_{\text {Sov }}^{2}\right) T}{\sigma_{\text {Sovs }} \sqrt{T}}=\frac{\ln \left(V_{\text {Sovs }} * \exp \left(\left(r_{f}+\frac{1}{2} \sigma_{\text {Sov }}^{2}\right) T\right)\right)-\ln \left(D_{f, s}\right)}{\sigma_{\text {Sovs }} \sqrt{T}}
$$

and

$$
d_{2}=\frac{\ln \left(\frac{V_{\text {Sovs }}}{D_{f, s}}\right)+\left(r_{f}-\frac{1}{2} \sigma_{\text {Sov }}^{2}\right) T}{\sigma_{\text {Sovs }} \sqrt{T}}=\frac{\ln \left(V_{\text {Sovs }} * \exp \left(\left(r_{f}-\frac{1}{2} \sigma_{\text {Sov }}^{2}\right) T\right)\right)-\ln \left(D_{f, s}\right)}{\sigma_{\text {Sovs }} \sqrt{T}}
$$

The volatility of $L C L_{\mathrm{s}}$ is estimated as:

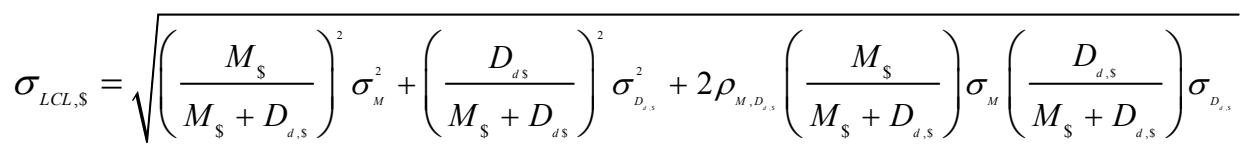

with

$$
\sigma_{D_{d, \mathrm{~S}}}=\sqrt{\sigma_{D d, L C}^{2}+\sigma_{X_{F}}^{2}-2 \rho_{D_{d}, X_{F}} \sigma_{X_{F}} \sigma_{D d, L C}^{2}}
$$

where $\sigma_{D d, L C}$ is the volatility of domestic debt in local currency, $\sigma_{X_{F}}$ is the volatility of the 1year forward exchange rate, and $\rho_{D_{d}, X_{F}}$ is the correlation between domestic debt in local currency and the 1-year forward exchange rate, and:

$$
\sigma_{M}=\sqrt{\sigma_{M, L C}^{2}+\sigma_{X_{F}}^{2}-2 \rho_{M_{L C}, X_{F}} \sigma_{X_{F}} \sigma_{M, L C}}
$$

where $\sigma_{M, L C}$ is the volatility of domestic debt in local currency, $\sigma_{X_{F}}$ is the volatility of the 1year forward exchange rate, and $\rho_{M_{\iota c}, X_{F}}$ is the correlation between domestic debt in local 
currency and the 1-year forward exchange rate, and $\rho_{M, D_{u}}$ is the correlation between domestic debt in foreign currency and base money in foreign currency.

Also, the following indicators can be estimated:

(1) 1-year and 5-years distance to distress $\left(D T D_{t}\right)$, which gives the number of standard deviations of sovereign asset value that is away from the foreign debt distress barrier $\left(D_{f, s}\right)$ :

$$
D T D_{t}=\frac{\ln \left(V_{\text {Sov }}\right)+\left(r_{f}-\frac{\sigma_{\text {Sov }}^{2}}{2}\right) T-\ln \left(D_{f, \$}\right)}{\sigma_{\text {Sov } \$} \sqrt{T}}
$$

(2) 1-year and 5-year risk neutral default probabilities $\left(R N D P_{t}\right)$ :

$$
R N D P_{t}=N\left(-\mathrm{d} \_2\right)
$$

(3) 1-year and 5-years credit default spreads ( spread $_{t}$ ):

$$
\text { spread }_{t}=\frac{-1}{t} \ln \left(\frac{V_{\text {sors }}}{D_{f, s} e^{-t, t}} N\left(-d_{1}\right)+N\left(d_{2}\right)\right)
$$

Application of this approach requires significant amount of information about each individual debt security issued in the country, including: (i) coupon; (ii) amount outstanding; (iii) maturity; (iv) current market price; (v) market (whether it is issued in the external or domestic markets); (vi) currency; (vii) coupon type (fixed, floating, or indexed to inflation); and (viii) coupon frequency. It also requires that time series on foreign and domestic interest rates and foreign exchange rates be available. 


\section{APPENDIX II. TeChNicAl ASPECTS OF SALM Modeling: SoME EXAMPLES}

In implementing the SALM framework, the modeling of variables such as interest and exchange rates and other macroeconomic variables is important for estimating the risk exposure of a country as a whole. This is because the net worth of the country is driven by the evolutions of these variables. For example, if the country is holding net financial assets, the domestic/foreign interest yield curve movement and/or the exchange rate movement will have an impact on the value of these assets. If the country is holding net liabilities, their movements will also affect the value of liabilities. Other macroeconomic variables, such as output gap, inflation, and short interest rate should be taken into account. In particular, the term structure of interest rates is influenced by developments in the macroeconomy and vice-versa, the short-term interest rate-a policy rate-is controlled by the central bank to conduct its monetary policy and the government's funding requirement is influenced by macroeconomic developments.

A way to estimate a sovereign's risk exposures is to generate risk indicators from stochastic simulations driven by changes in interest rates, exchange rates, and other macroeconomic variables. These risk indicators are, then, determined by the generated probability distributions and specific confidence levels. In essence, these indicators allow estimating gains and losses originating from market movements with a certain probability.

\section{A. Interest Rate Modeling}

Commonly used term structure models are the one-factor CIR (Cox, Ingersoll, and Ross, 1985) model, or its extensions, the NS (Nelson and Siegel, 1987) model, the HW (Hull and White, 1994a and 1994b) model, the HJM (Heath, Jarrow, and Morton, 1992) model, and the DK (Duffie and Kan, 1996) model. These modeling techniques of the yield curve are widely used by both developed and emerging markets (e.g., the CIR model is used, among others, by Denmark (Denmarks Nationalbank, 2000), Canada (Bolder, 2002) and Brazil (Silva, 2005); an extension of the NS model by Sweden (Jensen and Kjaergaard, 2005); the HJM model by Hungary (Réz, 2007)).

\section{Cox, Ingersoll, and Ross Model}

The model introduces a "square-root" term in the diffusion coefficient of the Vasicek (1977) model. In contrast to the Vasicek model, the instantaneous interest rate is always positive, and follows from the following differential equation:

$$
d r(t)=k[\theta-r(t)] d t+\sigma \sqrt{r(t)} d z(t)
$$

where: $r(t)$ is interest rate at instant $t$

$k$ is mean-reversion speed parameter

$\theta$ is long-term interest rate average

$\sigma$ is interest rate volatility 
$z(t)$ is Brownian motion.

The mean and variance of $r(t)$ conditional on $F s(s<t)$ are

$E\left\{r(t) \mid F_{s}\right\}=r(s) e^{-k(t-s)}+\theta\left(1-e^{-k(t-s)}\right)$,

$\operatorname{Var}\left\{r(t) \mid F_{s}\right\}=r(s) \frac{\sigma^{2}}{k}\left(e^{-k(t-s)}-e^{-2 k(t-s)}\right)+\theta \frac{\sigma^{2}}{2 k}\left(1-e^{-k(t-s)}\right)^{2}$

where $F s$ is a market movement at time $s$.

CIR 2 is the two-factor model, which models the instantaneous interest rate as:

$d r_{1}(t)=k_{1}\left[\theta_{1}-r_{1}(t)\right] d t+\sigma_{1} \sqrt{r_{1}(t)} d z_{1}(t)$

$d r_{1}(t)=k_{2}\left[\theta_{2}-r_{2}(t)\right] d t+\sigma_{2} \sqrt{r_{2}(t)} d z_{2}(t)$

where $z_{1}$ and $z_{2}$ are independent Brownian motions, and $k_{1}, \theta_{1}, \sigma_{1}, k_{2}, \theta_{2}, \sigma_{2}$ are positive constants.

The CIR2 allows for decoupling of short and long-term interest rates.

\section{Hull and White model}

Given their small number of parameters, the Vasicek and CIR models, do not necessarily match the term structure of interest rate observed in the market. This problem has been addressed by Hull and White in their 1994 papers. The HW model introduces a time-varying parameter in the Vasicek model:

$d r(t)=(v(t)-a r(t)) d t+\sigma d z(t)$

where $a$ and $\sigma$ are positive constants and $v$ is chosen to fit the interest rate term structure observed in the market. A drawback of this model is the theoretical possibility for $r$ to be negative.

\section{Nelson and Siegel model}

Nelson and Siegel (1987) introduced a model to fit the interest rate structure using a flexible, smooth parametric function:

$r_{t}(\tau)=\beta_{1, t}+\beta_{2, t}\left[\frac{1-\exp \left(-\frac{\tau}{\lambda_{t}}\right)}{\frac{\tau}{\lambda_{t}}}\right]+\beta_{3, t}\left[\frac{1-\exp \left(-\frac{\tau}{\lambda_{t}}\right)}{\frac{\tau}{\lambda_{t}}}-\exp \left(-\frac{\tau}{\lambda_{t}}\right)\right]$,

where $\tau$ is the maturity of the debt instruments. Parameters $\beta_{1, t}, \beta_{2, t}$, and $\beta_{3, t}$ and their components capture a range of monotonic, humped, and S-type shapes observed in the market. In particular, $\beta_{1, t}$ is a long-term component, since its component is 1 and remains the 
same for every maturity. The component of $\beta_{2, t}$ is a short-term one, because it starts at 1 and then decays to zero. The component of $\beta_{3, t}$ is a medium-term one, which starts at zero, increases for medium maturities and then decays to zero, therefore, capturing a humped shape. Note that $\lambda_{t}$ is the decay parameter, which determines at which maturity the components reach a maximum. Diebold and Li (2006) show that $\beta_{1, t}, \beta_{2, t}$, and $\beta_{3, t}$ can be interpreted as three factors that capture the level, slope, and curvature of the yield curve, and the dynamics of these factors can be estimated with time-series models.

\section{Heath, Jarrow, and Morton model}

Heath, Jarrow and Morton (1992) choose the instantaneous forward rates as fundamentals to model interest rates and, then, derive an arbitrage-free framework for the stochastic evolution of the entire yield curve.

\section{B. Exchange Rate Modeling}

For the real exchange rate, Brazil uses a CKLS model adopted with an exchange rate exponent $\gamma$ in the volatility term equal to one. ${ }^{25}$ This process is described as:

$$
d C_{t}=\beta\left(C^{*}-C_{t}\right) d t+\sigma_{2} C_{t}^{\gamma} d z_{t}
$$

where: $C_{t}$ is real exchange rate at time $t$

$\beta$ is mean reversion speed

$C^{*}$ is real exchange rate long-term average

$\sigma_{2}$ is real exchange rate volatility

$d z_{t}$ is Wiener process

The cost of carrying FX debt depends not on the real but, rather, on the nominal exchange rate. Nevertheless, it is possible to obtain the nominal rate from the real rate as long as we have the domestic and the external price indices.

\section{Broader Macroeconomic Modeling: Country Examples}

Countries model macroeconomic variables differently. Indicatively:

\section{Brazil}

The domestic price index follows a Geometric Brownian motion (GBM): ${ }^{26}$

\footnotetext{
${ }^{25}$ The CKLS (Chan, Karolyi, Longstaff and Sanders, 1992) model is a generalization of the CIR model.
} 


$$
d I_{t}=\mu I_{t} d t+\sigma_{3} I_{t} d z_{t}
$$

where: $I_{t}$ is price index at instant $\mathrm{t}$

$$
\begin{aligned}
& \mu \text { is average rate of growth of the price index } \\
& \sigma_{3} \text { is volatility of the price index } \\
& d z_{t} \text { is Wiener process }
\end{aligned}
$$

The external price index follows a deterministic process:

$$
d I_{t}^{e}=\mu^{e} I_{t}^{e} d t
$$

where: $I_{t}^{e}$ is external price index at instant $t$

$\mu^{e}$ is growth rate of the external price index

The nominal exchange rate can be calculated, by definition, as:

$$
N_{t}=\frac{I_{t}}{I_{t}^{e}} C_{t}
$$

Applying Ito's lemma to this last equation, and using the diffusion processes of the real exchange and of the domestic and external price indices, one can obtain the nominal exchange rate process.

Each of the three modeled primitive processes - interest rate (CIR model), real exchange rate and inflation - has a stochastic term, characterized by a Wiener process. However, those variables are correlated in practice. Economic relations among those variables would make it difficult, for instance, to imagine a situation in which those three variables increase jointly over time.

\section{United Kingdom}

It uses a NS model with macroeconomic factors, and runs vector auto-regressions: ${ }^{27}$

\footnotetext{
${ }^{26}$ See Cabral et al., 2008.

${ }^{27}$ See Pick and Anthony, 2006.
} 


$$
\begin{aligned}
& {\left[\begin{array}{c}
r_{t}\left(\tau_{1}\right) \\
\cdot \\
r_{t}\left(\tau_{N}\right)
\end{array}\right]=\left[\begin{array}{l}
1\left[\begin{array}{c}
1-\exp \left(-\frac{\tau_{1}}{\lambda_{t}}\right) \\
\frac{\tau_{1}}{\lambda_{t}}
\end{array}\right] \\
\cdot\left[\begin{array}{c}
\frac{1-\exp \left(-\frac{\tau_{1}}{\lambda_{t}}\right)}{\frac{\tau_{1}}{\lambda_{t}}}-\exp \left(-\frac{\tau_{1}}{\lambda_{t}}\right) \\
\cdot
\end{array}\right]\left[\begin{array}{l}
\beta_{1, t} \\
\beta_{2, t} \\
\beta_{3, t}
\end{array}\right]+\left[\begin{array}{c}
\varepsilon_{t}\left(\tau_{1}\right) \\
\cdot \\
\varepsilon_{t}\left(\tau_{N}\right)
\end{array}\right], \\
1\left[\frac{\tau_{N}}{\frac{\tau_{N}}{\lambda_{t}}}\right]
\end{array}\right],} \\
& {\left[\begin{array}{l}
\beta_{1, t} \\
\beta_{2, t} \\
\beta_{3, t}
\end{array}\right]=\left[\begin{array}{l}
\mu_{1} \\
\mu_{2} \\
\mu_{3}
\end{array}\right]+\left[\begin{array}{lll}
a_{11} & a_{12} & a_{13} \\
a_{21} & a_{22} & a_{23} \\
a_{31} & a_{32} & a_{33}
\end{array}\right]\left[\begin{array}{l}
\beta_{1, t-1} \\
\beta_{2, t-1} \\
\beta_{3, t-1}
\end{array}\right]+\left[\begin{array}{lll}
b_{11} & b_{12} & b_{13} \\
b_{21} & b_{22} & b_{23} \\
b_{31} & b_{32} & b_{33}
\end{array}\right]\left[\begin{array}{l}
X_{1 t} \\
X_{2 t} \\
X_{3 t}
\end{array}\right]+\left[\begin{array}{l}
\eta_{1 t} \\
\eta_{2 t} \\
\eta_{3 t}
\end{array}\right],} \\
& \text { where }\left[\begin{array}{c}
X_{1 t} \\
X_{2 t} \\
X_{3 t}
\end{array}\right] \text { are the macroeconomic variables. }
\end{aligned}
$$

\section{Sweden}

It assumes the parameters $(\beta \mathrm{s})$ in the interest rate model (NS), inflation, and the exchange rate follow stationary stochastic processes (Ornstein-Uhlenbeck processes) ${ }^{28}$ :

$d X=\alpha(\bar{X}-X) d t+\sigma d z$

where $\alpha$ controls the speed at which $X$ return to its mean level $\bar{X}$, and $d z$ is a Wiener process with volatility $\sigma$.

The estimation of parameters in the interest rate, exchange rate, and other macroeconomic models requires inputs of historical data series. For domestic interest rate modeling, liquid market data that span a long time period are needed in order to improve the accuracy of estimation. In two-factor or multi-factor interest rate models, a market-determined yield curve is imperative. In emerging market and developing economies that do not have long-time data series on interest rates, there is often a limitation in using interest rate modeling. Problems in the data adequacy of other variables may also impede the adoption of such modeling approaches. In general, it is relatively easier to estimate the parameters of a foreign interest rate model, since data series on rates tend to be more readily available and relatively more reliable — coming from deep and highly liquid markets.

\footnotetext{
${ }^{28}$ See Bergstrom, Holmlund and Lindberg, 2002.
} 